\title{
THE APSE MOSAICS IN THE CHURCH OF SAN MAURO AT PARENTIUM: A JUSTINIANIC INTERPRETATION
}

\section{THOMAS E. SCHWEIGERT}

UDC: $75.052 .033 .2(497 \cdot 571)$

Original scientific paper

Manuscript received: 02. 11. 2016.

Revised manuscript accepted: 17. 03. 2017.

DOI: 10.1484/J.HAM.5.113757
T. E. Schweigert

University of Wisconsin-Whitewater Whitewater WI, 53190

USA

schweigt@uww.edu

The mosaics of the church of San Mauro in ancient Parentium are published in an invaluable study by Terry and Maguire (Dynamic Splendor). They accept that bishop Eufrasius, a "Three Chapters" schismatic, was the intellectual author of the mosaics which contain schismatic elements. I contend the church was consecrated before the 559 schism, which was a break with Rome over ecclesial authority, rather than opposition to Justinian's Fifth Ecumenical Council Constantinople II. I see San Mauro as a rare survival, a Justinianic church of the Theotokos, and an example of imperiallurban renewal in an Istria definitively reconquered in the first months of the Gothic War. The central apse mosaic can be read as a visual statement of three canons from Constantinople II: 1) the doctrine of Theotokos, Mary as mother of the incarnate Word; 2) the oneness of Christ after the hypostatic union; 3) the Theopaschite Formula, "One of the Trinity suffered in the flesh". The side apses reflect Justinian's personal devotion to Saints Cosmas and Damian and his elevation of the see of Ravenna to arch-episcopal status under his close associate, Maximian.

Keywords: Byzantine mosaics, Three Chapters Schism, Justinian I, Fifth Ecumenical Council

The church of San Mauro (aka Eufrasiana) ${ }^{1}$ in ancient Parentium (fig. 1), in the Istrian part of Venetia et Histria $(V \mathcal{E} H)$, preserves sixth century wall mosaics comparable to, and contemporary with, those of Ravenna at San Vitale, Sant'Appolinare Nuovo and Sant'Appolinare in Classe (fig. 2). The indispensable two volume work of Terry and Maguire ${ }^{2}$ publishes these mosaics, which are only viewed with difficulty in situ, owing to the obtrusive (iconoclastic?) presence of a thirteenth century, Venetian-installed ciborium over the main altar. While there are no documentary sources that explicitly date San Mauro, Terry and Maguire find ample physical evidence for the age of Justinian in the form

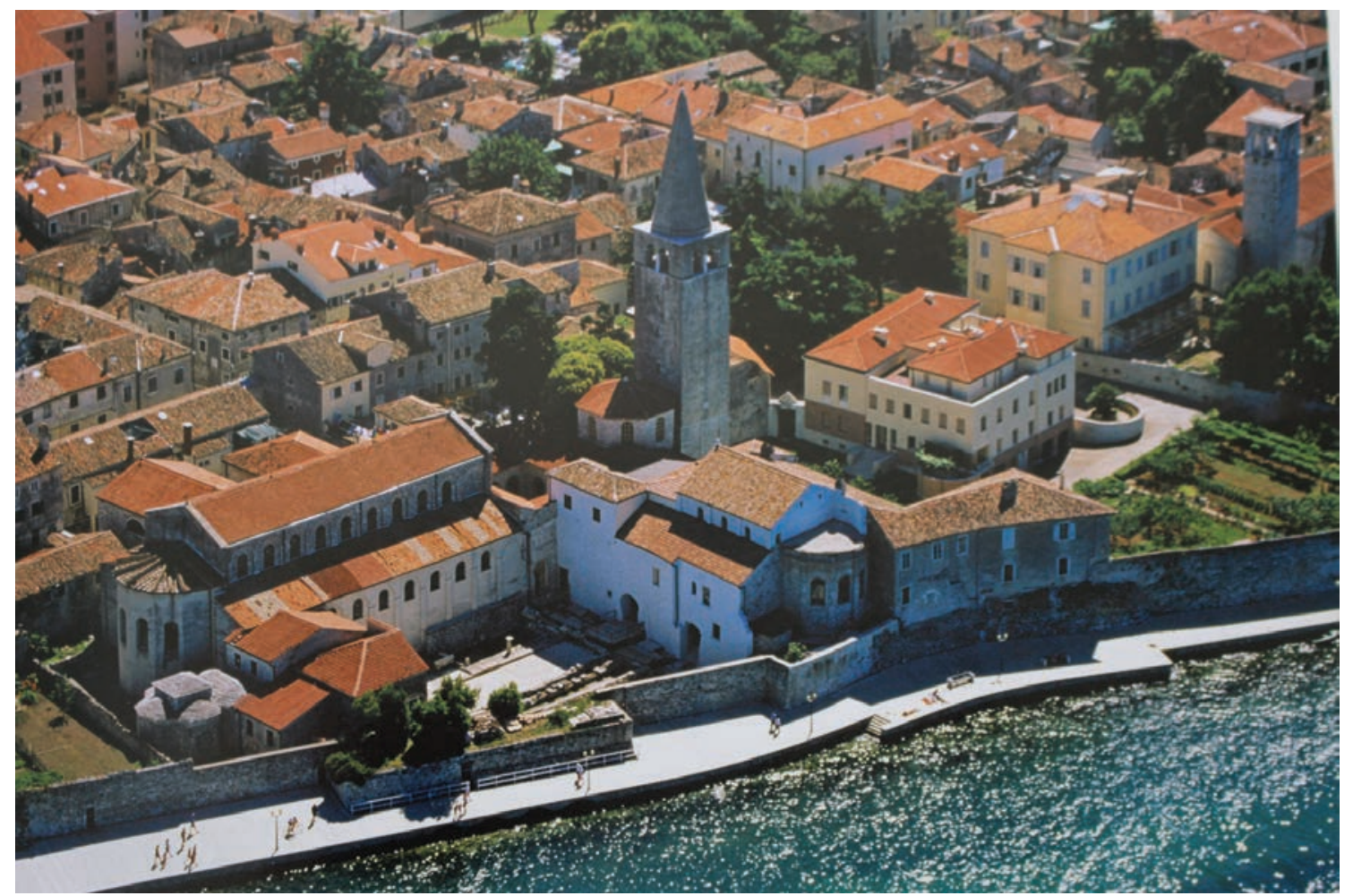

Fig. 1: Adriatiac sea, circuit wall, Eufrasian episcopal complex [three-apsed basilican cathedral, baptistry, bell tower, episcopal palace]. Parenzo/Poreč (Parentium).

\footnotetext{
${ }^{1}$ The episcopal complex in present day Parenzo/Poreč in Croatian Istria is now called the Eufrasiana for bishop Eufrasius. The church was orgininally the Church of Sanctus Maurus or, in Italian/Slavic, San Mauro/Sveti Maur. I use San Mauro in conformity with San Vitale, etc., in Ravenna. For ancient Parentium (and the historical Saint Maurus) see A. POGATSCHNIG, Parenzo, dalle origini sino allimperatore Giustiniano (Parenzo: G. Coana, 1910, p. 18-20). ${ }^{2}$ A. TERRY, H. MAGUIRE, Dynamic Splendor: The Wall Mosaics in the Cathedral of Eufrasius at Poreč, 1: Text, 2: Illustrations, University Park PA, 2007.
} 


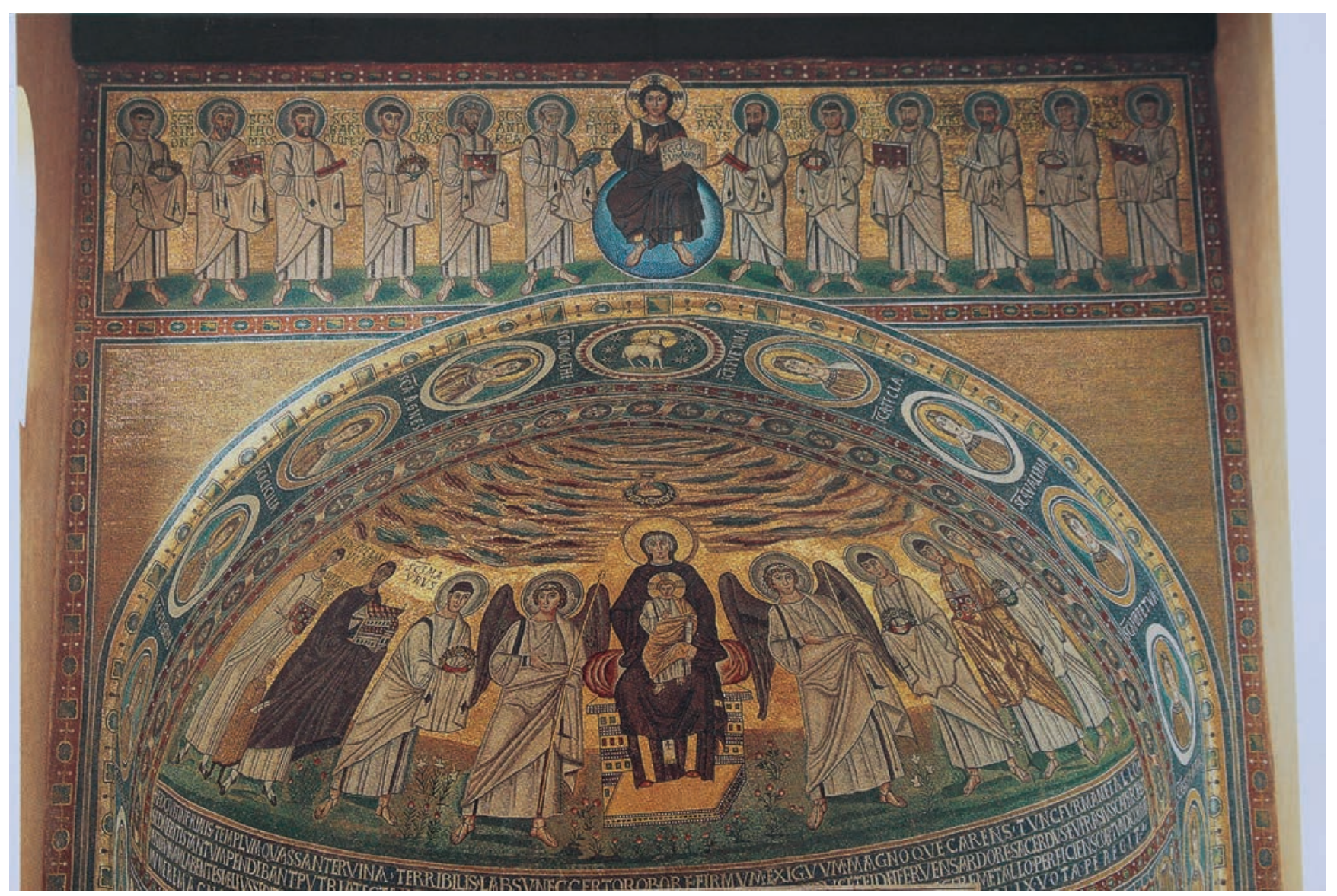

Fig. 2: Mosaics of triumphal arch and semi-dome of central apse. Church of San Mauro. Parenzo/Poreč (Parentium).

of the same mason's marks on the Proconessian marble at San Mauro as at San Vitale, the latter "probably completed ... before its dedication in 547-48"3. Their extensive "list of sculptural parallels" with San Mauro includes not only those at San Vitale, but also at Sant'Apollinare in Classe (decicated in 549) and even at Hagia Sophia in Constantinople, completed in 5374. Unlike the Justinianic claims for sculptural elements, Terry and Maguire's interpretation of certain aspects of the iconography of the mosaics at San Mauro rests on the premise that the intellectual author of the mosaic program was the then bishop, Eufrasius ${ }^{5}$, who was at the time a "Three Chapters" schismatic, under attack from the bishop of Rome, Pelaguius I ${ }^{6}$. Thus, the mosaic program is read, in part, as containing both schismatic motifs and self-defensive Eufrasian propaganda7. However, the so-called "Three Chapters" schism in VEFH only began in 559, so, for this to be the case, the mosaic decoration would have to date from the 56 os $^{8}$. And "so-called" because, as I will contend, rather than being about theological issues from an ecumenical council held six years previously, the schism was fundamentally a dispute between Pelagius and the metropolitan bishops of Mediolanum and Aquileia over ecclesial authority - who can consecrate a bishop - on an Italian peninsula that had just been unified and reunited with the Empire by Justinian. Pelagius was asserting that, in contrast with "ancient custom", he alone could consecrate these bishops at a ceremony to be performed in Rome. The letters of Pelagius are the principal source for the schism 9 . These letters together with information contained in the mosaics themselves, and the so-called Privilege of Eufrasius together with an inscription on the Altar of Eufrasius, comprise two independent sets of evidence that suggest, with high probability, a completion date well before 559, that is, before the schism, and also in line with the sculptural evidence for dating presented by Terry and Maguire ${ }^{10}$.

I argue for San Mauro as a rare survival, a Justinianic church of the Theotokos, many of which were built in areas reconquered from the Persians and Vandals in Syria,

\footnotetext{
3 Ibidem , p. 60.

${ }^{4}$ Ibid.

${ }^{5}$ For Eufrasius, see EUFRASIUS, in Prosopographie Chrétienne du Bas-Empire, 2, Prosopographie de L’Italie Chrétienne (313-604), 1, eds. C. Pietri, L. Pietri, Rome, 1999, p. 671-72.

${ }^{6}$ For the Three Chapters see R. PRICE, trans., The Acts of the Council of Constantinople of 553, with related texts on the Three Chapters Controversy, vols. 1 and 2, Liverpool, 2009, 1, p. 16-28, and A. GRILLMEIER, T. HAINTHALER, Christ in Christian Tradition, 2, From the Council of Chalcedon to Gregory the Great, part 2, The Church of Constantinople in the sixth century, trans. J. Cawte and P. Allen, London, 1995, p. 411-461.

7 TERRY, MAGUIRE, Dynamic Splendor, 1, p. 59, 69, 129-133.

${ }^{8}$ For the Three Chapters schism in Italy see Claire SOTINEL, "The Three Chapters and the Transformation of Italy" and other papers in The Crisis of the Oikoumene: The Three Chapters Controversy and the Failed Quest for Unity in the Sixth-Century Mediterranean, eds. C. Chazelle, C. Cubitt, Turnhout, 2007 (Studies in the Early Middle Ages).

9 PELAGIUS I, Epistulae quae supersunt (556-561), eds. P. M. Gassó, C. M. Batlle, Montserrat, 1956 (Scripta et Documenta, 8). All translations from Pelagius are by the author.

${ }^{10}$ Terry and Maguire mention all of these but do not use them to adduce a date.
} 
Palestine and North Africa, of which only Saint Catherine's Monastery survives in the Sinai ${ }^{11}$. The relevant context, then, is not opposition to Justinian's religious policy, but imperial restoration and urban renewal as the result of a decisive early victory in the Gothic War on the eastern shore of the Adriatic (including Istria), in contrast to the situation on the Italian Peninsula. The iconography of the mosaics actually promotes imperial religious policy, as well as reflecting the personal piety of Justinian and the new prominence of the see of Ravenna, elevated by Justinian to an archbishopric ${ }^{12}$. The central images of the central apse mosaic can be read as a visual statement of at least three canons of the Fifth Ecumenical Council, or Second Council of Constantinople - Constantinople II: the Virgin Mary as Theotokos (Canon 6); the oneness of Christ after the hypostatic union (Canon 8); theopaschism - One of the Trinity suffered in the flesh (Canon 10 $)^{13}$. The north apse depicts Cosmas and Damian, whom Justinian credited with having miraculously saved him after his doctors had given him up for dead, a victim of the "Justinianic plague" of $541^{-5} 52^{14}$. In the south apse we discern the hand of the Ravennate bishop and close associate of Justinian, Maximian ${ }^{15}$, in the representation of Saints Severus and Hermagorus, former bishops of, respectively, Ravenna and Aquileia. Saint Severus, wearing the pallium and representing Ravenna, is depicted on an equal footing with Saint Hermagoras, who represents the see of Aquileia to which Parentium had traditionally been suffragan. This paper first presents the evidence for the dating of San Mauro relative to the outbreak of schism in $V \mathcal{E} H$. It then considers Justinian's intertwined religious, military and urban/imperial renewal policies to contextualize a Justinianic interpretation of the apse mosaics at San Mauro.

\section{A “THREE CHAPTERS" SCHISM IN VENETIA ET HISTRIA?}

As bishop of Rome, Pelagius I exercised direct ecclesial authority in Italia Suburbicaria, but he encountered resistance when he tried to extend that authority to Italia Annonaria - Liguria, Venetia and Aemilia, with the major bishoprics of Mediolanum, Aquileia and Ravenna. Seven of his letters from early 559 deal with the schism in $V \mathcal{E} H$, two letters to John the Patricius ${ }^{16}$, two letters to Agnellus, bishop of Ravenna ${ }^{17}$, two letters to Valerian the Patricius ${ }^{18}$, and a letter to Justinian's victorious general, the eunuch Narses. In the first ${ }^{19}$, Pelagius writes to John complaining of how badly "schismatic prelates" (schismatici praesules) in $V \mathcal{E} H$, especially the new bishop of Aquileia, Paulinus, now styling himself "patriarch of Aquileia" ${ }^{20}$, have treated him, accusing him of having "acted against synods". This is the first use by Pelagius in his extant letters, which begin in 556 , of the word schismaticus ${ }^{21}$. Pelagius begins with a rhetorical question. Did anyone from the Venetias, particularly the "patriarch of Istria" [sic] - Histryae patriarcha - ever attend a general council or send delegates? ${ }^{22}$ The implied answer being, no, how then can they judge that Pelagius did something contrary to synods? If they had concerns "they ought to have diligently inquired" ${ }^{23}$, but there is no mention of direct communication between Pelagius and the Mediolanum and Aquileia metropolitans. Having dismissed their charges against him as groundless, Pelagius launches into a vitriolic attack on Paulinus, likening his consecration to a desecration and an execration, rejecting it as non-canonical and invalid, and referring to him as the "chief priest [ponti$f e x]$ of the foremost heretics" ${ }^{24}$. He has ruined both a monk - himself - "if indeed he ever was one" ${ }^{25}$, and the episcopate, which he allegedly obtained through bribery. Pelagius describes the "ancient custom" (mos antiquitus) by which the Mediolanum and Aquileia metropolitans consecrate each other: "certainly the custom was very old that, because of the distance from the Apostolic see or the difficulty of the journey, it was onerous for them to be ordained, the Mediolanum and Aquileia bishops had been obliged to ordain each other in turn; so that to the city in which the bishop had to be ordained, the pontifex of the other city had to go"26.

\footnotetext{
"Saint Maurus as a Justinianic church of the Theotokos is also argued by D. MILINOVIĆ, Le programme iconographique de la mosaïque de l'abside centrale de la basilique d'Euphasius de Poreč en Croatie: le patronage de l'empereur el le rôle de la Theotokos, in Romanité et Cité Chrétienne: Mélanges en l'honneur d'Yvette Duval, Paris, 2000, p. 359-370. The connection between Justinianic restoration in Africa and in the upper Adriatic is argued by S. TAVANO, La Restaurazione Giustinianea in Africa e nell'alto Adriatico, in Aquileia e l'Africa, Udine, 1974, p. 251-283.

${ }^{12}$ On the promotion of the see of Ravenna to archbishopric by Justinian at the time of Maximian, see Robert A. MARKUS, "Carthage - Prima Jusintiana Ravenna", in From Augustine to Gregory the Great, XIII, London, 1983, p. 292-299.

13 PRICE, The Acts, 2, p. 121-122.

${ }^{14}$ As described in PROCOPIUS OF CAESAREA, Buildings, in Procopius, VII, trans. H.B. Dewing, London, 1962, p. 39.

${ }^{15}$ For Maximian see MAXIMIAN in Agnellus of Ravenna, The Book of Pontiffs of the Church of Ravenna (LPR), trans. D. MAUSKOPF DELIYANNIS, Washington DC, 2004, p. 184-197; MAXIMIANUS 2 in Prosopographie, 2, 1446-1452; and MARKUS, "Carthage", p. 292-299.

${ }^{16}$ Iohannes Patricius, John the Patricius, of Pelagius's letters is almost certainly John, the nephew of Vitalian, in Procopius's The Gothic War. See IOHANNES 35, in Prosopographie, 1083-84.

${ }^{17}$ Agnellus, (arch)bishop of Ravenna [556-570], successor of Maximian. See AGNELLUS 3, Prosopographie, 59-63, and AGNELLUS in Agnellus of Ravenna, LPR, 198-204. To avoid confusion, the ninth century author is always referred to as Agnellus of Ravenna to distinguish him from bishop Agnellus.

${ }^{18}$ Valerianus Patricius, Valerian the Patricius, of Pelagius's letters is almost certainly the general in Procopius active in Asia, Africa and Europe. Together with his brother-in-arms, John, they led a naval victory over the Goths in 551 at Ancona that "broke the spirit and weakened the power of Totila and the Goths". PROCOPIUS OF CAESAREA, History of the Wars, Book VIII. The Gothic War (cont.), in Procopius, V, p. 287-303. See also VALERIANUS 3 , Prosopographie, 2239-2240.

${ }^{19}$ Pelagius I, Ep. 24, 73-78.

${ }^{20}$ This may be the first mention of "patriarch" for the bishop of Aquileia, a title borne to this day by the archbishop of Venice.

${ }^{21}$ In a letter from 557 to seven bishops of Tuscia Annonaria - Tuscany north of the Arno - Pelagius admonishes their scisma, but does not refer to them as schismatics. Significantly, he writes directly to them, something he didn't do in the case of the northern metropolitans. See Pelagius I, Ep. 10, 31-34.

${ }^{22}$ Pelagius I, Ep. 24, 73-76.

${ }^{23}$ Ibidem, 74.

${ }^{24}$ Ibid., 75 .

25 Ibid.

${ }^{26}$ Ibid., 76 .
} 
The technicality pointed to by Pelagius is that Paulinus went to Mediolanum to be consecrated by Auxanus ${ }^{27}$, rather than the Mediolanum consecrating bishop going to Aquileia. More importantly, though, this was done without the involvement of Pelagius: "He [Paulinus] who refuses to be consecrated in the universal church, by no reason can it be said that he is consecrated. Divided from the flesh of the church and separated from apostolic sees, that one [Auxanus] desecrates rather than consecrates" 28 . Pelagius is careful to use the plural, apostolic sees, in his communications with imperial officials, but, by "universal church" and "apostolic sees," Pelagius can only be referring here to himself. At issue is the "ancient custom" which allows the northern metropolitans to consecrate each other independently of Rome, though this is condescendingly portrayed by $\mathrm{Pe}$ lagius as a mere occasional convenience, when the "distance" and "difficulty" of the journey to the Apostolic see is too

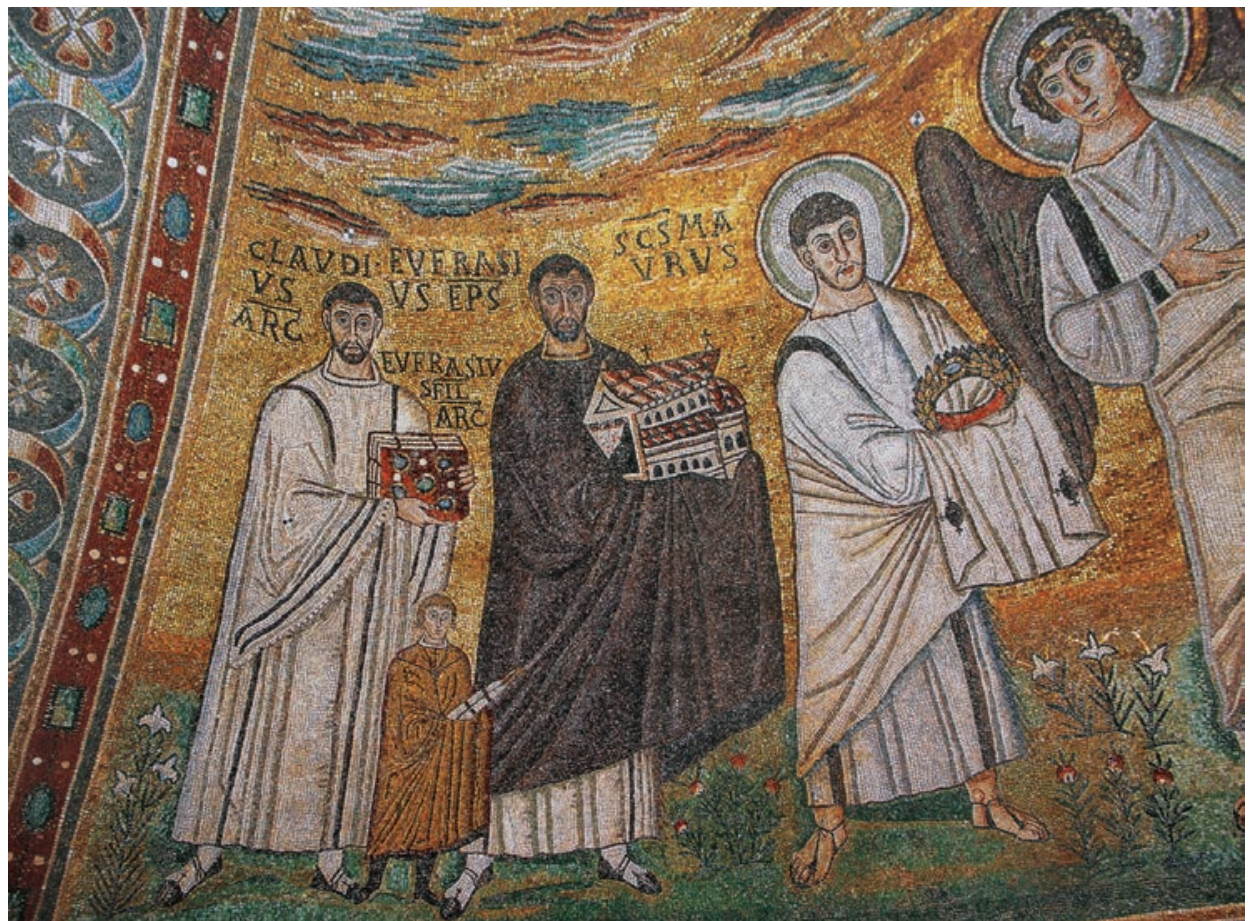

Fig. 3: Central apse mosaic, left side, from left to right: Claudius, Claudius's son Eufrasius, bishop Eufrasius, Saint Maurus, angel (Archangel Michael?). Church of San Mauro. Parenzo/Poreč (Parentium). onerous. Pelagius concludes by admonishing John to have nothing to do with the schismatics, implying John is "in communion" with them at the time Pelagius writes.

In the next letter, the first one to Agnellus, Pelagius seems to be trying to force the bishop of Ravenna to take his side against the northern metropolitans ${ }^{29}$. In the third letter, the first to Valerian ${ }^{30}$, Pelagius demands that he and John go to Aquileia and "make use of appropriate and rightful power" for "schism is evil and such men ought to be crushed by external forces, as the authority of canonical scripture and the truth of ancestral rules teaches us" ${ }^{31}$. He could have closed with "let those who dared such things be sent to the most pious princeps [Justinian] under strict custody" ${ }^{2}$, but Pelagius further exhorts Valerian to follow his own example when, in the spring of 552, with the Franks occupying Venetia and bishop Datius ${ }^{33}$ of Mediolanum having died in Constantinople, Valerian prevented a new bishop of Mediolanum from being consecrated until the candidate received the approval of Justinian ${ }^{34}$. Thus Pelagius uniquely informs us that Datius, staunch opponent of Justinian's condemnation of the Three Chapters, had as his successor someone personally approved by Justinian. Pelagius further asks Valerian to recall how he took the Mediolanum bishop-elect and his Aquileian consecrator across the war-torn countryside to Ravenna for the consecration. Pelagius doesn't mention
Maximian, but the bishop (or newly created archbishop) of Ravenna certainly presided over the consecration in the restored imperial capital, perhaps in the presence of Narses who was likely there. From medieval episcopal lists these bishops, anonymous in Pelagius's account, are Vitalis of Mediolanum and Macedonius of Aquiliea ${ }^{35}$. Macedonius is succeeded in 559 by Paulinus, consecrated in Mediolanum by Vitalis's successor, Auxanus. We can thus infer that the immediate predecessors of Paulinus of Aquileia, and Auxanus of Mediolanum were not "Three Chapters" schismatics in opposition to either Justinian or the (arch)bishop of Ravenna, and there is no evidence for that having changed for their successors in 559, or thereafter ${ }^{36}$. The schism, then, was exclusively a break with Rome over the issue of ecclesial authority on the Italian peninsula, rather than a council that had been held six years in the past.

In the second letter to John, Pelagius praises God that the schismatics in $V \mathcal{E} H$ have excluded him from their communion, saving him from their pollution (and making him a potential ally). He again tells John to "remove such ones from that province, make use of the opportunity bestowed on you by God of crushing the faithless ones. For then it can be fully accomplished, if the authors of wickedness, especially the usurper [Paulinus] of the church of Aquileia, who is cursed both in schism and by a schismatic, can be

\footnotetext{
${ }_{27}$ Pelagius never names “that Mediolanum bishop" who in later episcopal lists is identified as Auxanus. See AUXANUS, Prosopographie, 237-238.

${ }^{28}$ Pelagius I, Ep. 24, 75-76.

${ }^{29}$ Pelagius I, Ep. 50, 131. I differ with Markus on the reading and interpretation of this letter as an "expression of [Pelagius's] sense of lonely partnership between their two sees". I see Pelagius bullying Agnellus to take his side. See R.A. MARKUS, Ravenna and Rome, 554-604, in From Augustine, XIV, 568. 
directed to the most merciful princeps [Justinian], that he will be able to maintain neither the honor nor the reward of bishop" ${ }^{37}$. Paulinus here is not only cursed "in schism" but "by a schismatic", a reference to his consecrator. In this letter, Pelagius also mentions by name one Eufrasius:

The sins of Eufrasius, which God no longer wished to be hidden, vividly form an idea for you of the kind of ones who are fleeing the church, [Eufrasius] who in homicide considered not even the bonds of humanity, nor the love of a brother, nor the respect of the priesthood. Incestuous moreover in adultery, he has even removed the way of punishment itself, for, if you punish adultery, nothing remains on which incest may be punished; if for incest you heap retribution, the crime of adultery goes scot-free ${ }^{38}$.

This Eufrasius, though not explicitly identified as such, has been taken to most likely be the homonymous bishop of Parentium depicted in the mosaic of the central apse at San Mauro (fig. 3). It is solely on the basis of this passage that some have concluded that San Mauro was built by a "Three Chapters" schismatic bishop. Pelagius's use of the sordid tale of the "sins of Eufrasius" - priest killer, fratricide, and widowed sister-in-law fornicator! - as an added rhetorical inducement in his final appeal to John apparently fell on deaf ears. In the final letter to Valerian, Pelagius laments that "against the will of the pontifex" Valerian has asked Paulinus to accept John back into his communion ${ }^{39}$. Pelagius did not want John "in communion" with Paulinus "because both from you and from [John] we demanded and now again we demand that both Paulinus, pseudo-bishop, and that Mediolanum bishop, you direct under strict guard to the most merciful princeps" 40 .

In his letter to a Narses "indifferent to vengeance" against those "who tear the church to pieces"41, Pelagius exhorts the eunuch general in a mocking tone to "get his courage up" Erigite ergo animum vestrum ${ }^{42}$. The schismatics who "boast of their lack of sophistication" -rusticitas - and "lacerate the body of Christ, that is, holy church" ${ }^{43}$ should be punished by the state - per publicas potestates - by being banished and subjected to harsh imprisonment, their property confiscated. The "indifference" of Narses cannot but be a reflection of that of the emperor himself. If Justinian had considered these bishops as treasonous opponents of his religious policy, there can be no doubt but that they would have suffered consequences ${ }^{44}$. In the final letter, Pelagius tells bishop Agnellus that he has given the schismatics ten days to submit, ${ }^{45}$ and, if they don't, he demands that Angellus condemn them as heretics. Whereas in his earlier indictments made to the imperial officials, Pelagius accuses the meteropolitans of violating church canons that have the force of law, in the letter to Agnellus, they have become Nestorian(!) heretics: "know what has still been held onto by such ones from the time of Celestine of blessed memory, Nestorius, whose dogmas and followers in this affair they uphold" 46 . One senses desperation on the part of Pelagius; with his entreaties to secular powers falling on deaf ears, he resorts to the charge of heresy. This ends not with a bang but a whimper, that of Pelagius. The next extant letter is to another John, comes patrimonii, with whom Pelagius has corresponded about similar problems in Aemilia ${ }^{47}$. In this brief, cryptic response with no extant antecedent, Pelagius declaims that "The law of the empire denies all power to the one who fraudulently has acquired it from the emperor," and "those who in truth succeed by deception or false entreaties receive no remedy" 48 . I concur with Markus that this is Pelagius's resigned response upon hearing that the emperor himself has sided with Pelagius's opponents ${ }^{49}$. Presumably Justinian did not intend that his reconquest of the Italian Peninsula should empower the bishop of Rome to assert "universal" authority outside of Italia Suburbicaria ${ }^{50}$.

\section{TWO EUFRASIUSES, OR ONE? BUT WHAT ABOUT THAT OTHER EUFRASIUS?}

Pelagius's second letter to John is the evidence linking San Mauro to the schism in VEH through the person of Eufrasius. But is the bishop of Parentium the same Eufrasius denounced in the letter? The Prosopographie chrétienne du bas-empire: Italie (313-604) (henceforth $P C$ ) contains entries on some 3,80o named male individuals who are attested in contemporary sources $^{51}$. Of these, there is only one Eufrasius, the bishop of Parentium. To put that in perspective, the $P C$ lists

\footnotetext{
37 Pelagius I, Ep. 53, 142.

${ }^{38}$ Pelagius I, Ep. 53, 141-42.

39 Pelagius I, Ep. 59, 155-158.

${ }^{40}$ Ibid., 156.

${ }^{41}$ Pelagius I, Ep. 6o, 159-161.

${ }^{42}$ Ibid., 160.

43 Ibid., 160-161.

${ }_{44}^{4}$ This was the case with the serious opposition to the condemnation of the Three Chapters in Africa that lasts up to the time of the council in 553 , but by 559 only a few diehards continued to pay a price for opposing the emperor. See PRICE, The Acts, 1, 31. Price describes the schismatics of northern Italy discussed here as "defying pope, council and emperor". See PRICE, The Acts, 1, p. 32. In my opinion, if they had really defied the emperor, they would have paid the same price as the Africans; they were defying Pelagius, using his involvement with the council as pretext.

${ }^{45}$ Pelagius I, Ep. 74, 187-188.

${ }^{46}$ Ibid., 188. Celestine I was pope at the time of Ephesus I and the condemnation of Nesorius in 431.

${ }_{47}$ Pelagius I, Ep. 75, 189-19o. For this John, see IOHANNES 52, Prosopographie, 1097.

${ }^{48}$ Ibid., 187.

49 MARKUS, "Ravenna and Rome", 569-570.

$5^{50}$ Of the nine bishops of Rome during the reigns of Justin I and Justinian I, only John I and John II ("Mercury") were "nontroublesome" for the emperor. See KELLY, Popes, p. 52-64.

${ }^{51}$ I counted the names of the first volume (1226 pages!) and multiplied by two to extrapolate the second. My count excludes a large number of individuals, none named Eufrasius, who are not attested contemporaneously. The name Paulus, for example, occurs 46 times, but there are five additional Pauluses not contemporaneously attested.
} 


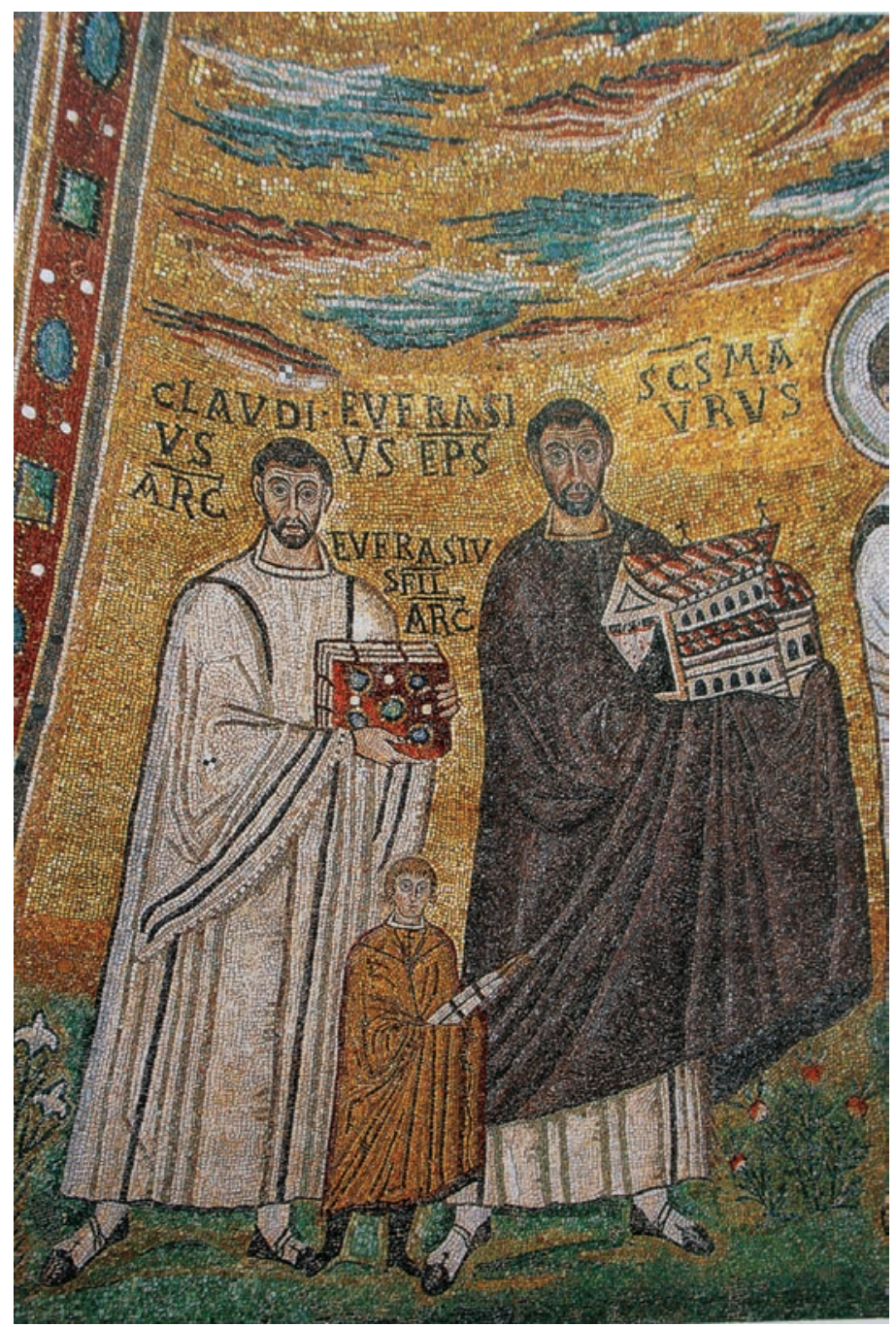

Fig. 4: Archdeacon Claudius, Archdeacon's Son Eufrasius, Bishop Eufrasius. Church of San Mauro. Parenzo/Porec (Parentium).

four Lucifers, three of them bishops. There are eight Mercurys (Mercurius), one of whom, upon becoming bishop of Rome, thought it appropriate to change his pagan name, becoming John II and setting a precedent. Significantly, when Pelagius writes to John the Patricius (who would have known everyone who was anyone in $V \mathcal{E} H$ ) about Eufrasius, he doesn't specify the one to whom he is referring, because there couldn't have been very many. Using the relative frequency of one in 3,800 as a probability, the probability that the Eufrasius of the letter is NOT some other Eufrasius, but rather the bishop, is .99974 - one to four decimal places ${ }^{52}$.

But there is another Eufrasius, and he's right there in the central apse mosaic (fig. 3). In the group to the left, three living humans are being led by Saint Maurus towards Theotokos (fig. 4). Inscriptions identify them as, from left to right, the arch-deacon Claudius [CLAVDIVS ARC(hdiaconus)], Claudius's son Eufrasius [EVFRASIVS FIL(ius) ARC(hdiaconi)], and bishop Eufrasius [EVFRASIVS $E P($ iscopu $) S]$, the latter holding a model of the church (fig. 4). The entry on Claudius in the $P C$ considers him to be "very probably the brother of the bishop" 53 , a surmise owing to the prominent position of the arch-deacon in the mosaic, the

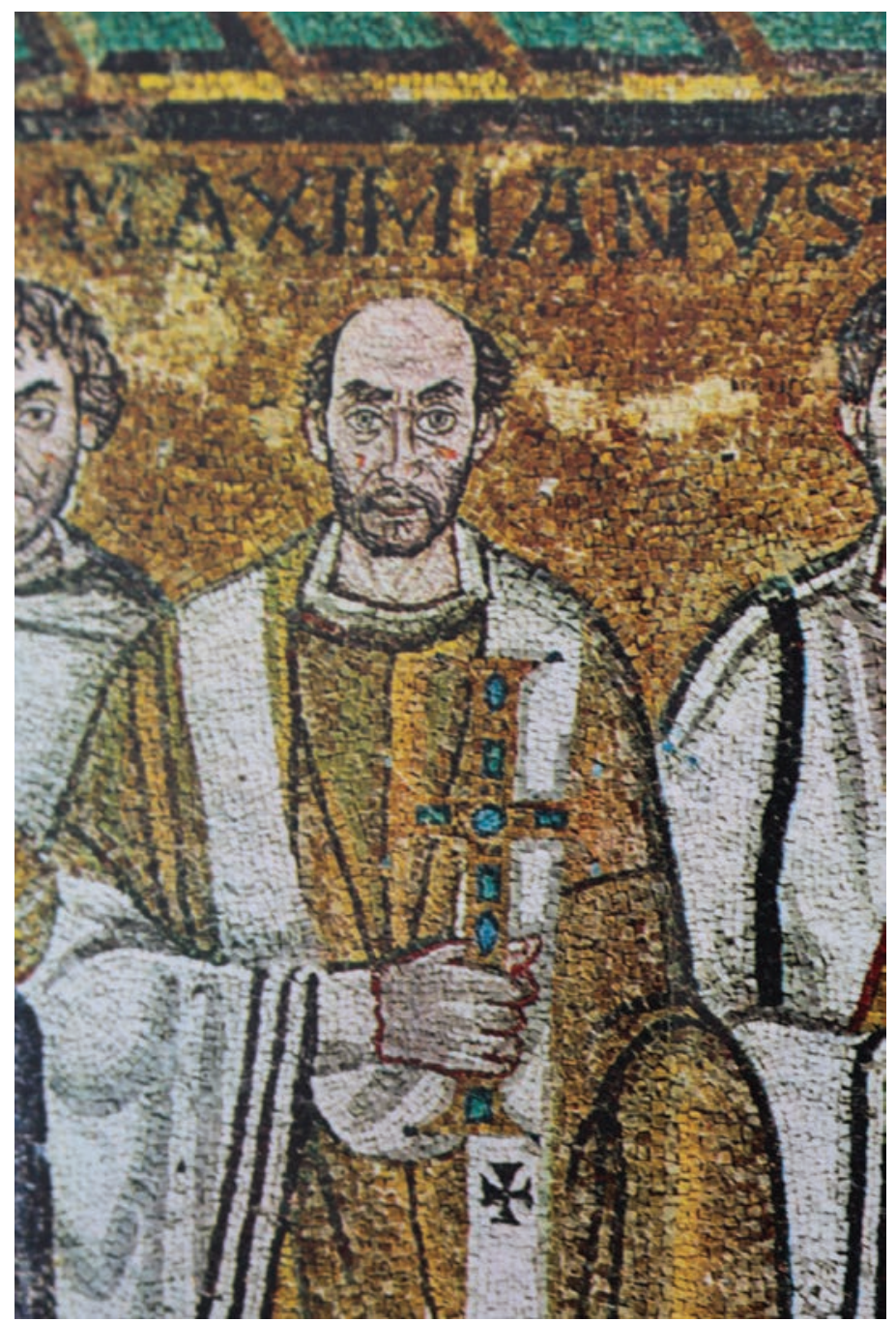

Fig. 5: Bishop Maximian of Ravenna, left apse wall. Church of San Vitale. Ravenna.

similarity in appearance between Claudius and Eufrasius, and the arch-deacon's son having the same name as what would then be his prominent uncle. But were the artists attempting here to create portrait likenesses? At San Vitale in Ravenna there are contemporary mosaic portrait likenesses, and unflattering ones at that, of living individuals such as Maximian (fig. 5). Terry and Maguire find the face of the Eufrasius figure to be the most finely detailed portion of the mosaic and to be very similar in execution to the Maximian figure in Ravenna ${ }^{54}$. I take the similarity in appearance of Claudius and Eufrasius to be intentional and concur with the $P C$ that Claudius is "very probably" Eufrasius's brother. But Pelagius alleges that Eufrasius murdered his own brother, a priest, and is now having sex with his widowed sister-in-law. Whether Eufrasius did this or Pelagius is making a false accusation, it is highly improbable that Pelagius, a skilled political operative, would make a groundless charge in an effort to influence a man such as John, the highest ranking imperial official in a region with which he was intimately familiar, as we know from multiple passages in Procopius's Gothic War. Pelagius's charge of homicide would be groundless if the alleged victim were not in fact dead. Eufrasius "very probably"

\footnotetext{
$5^{2}$ Using one in 3,800 as the probability, $P(\cdot)$, of someone (else) having the name Eufrasius $(E)$, then $P(E)=.00026$. The probability, then, that this is not some other Eufrasius is 1-.00026=.99974 (one to four decimal places).

${ }_{53}$ One has to go to the entry on Claudius in the $P C$, as this is not mentioned in the entry on Eufrasius. See CLAUDIUS 5 , Prosopographie, 449.

54 TERRY, MAGUIRE, Dynamic Splendor, 1, p. 63-64, 79 and 110-111.
} 
had at least one brother who was a priest, Claudius. Claudius was married, as he had a legitimate son named Eufrasius. It is possible that Eufrasius had yet another brother who was a married priest, but that would be pure speculation. I conclude that Cladius was "very probably" dead in 559, but he is very much alive in the mosaic, which then "very probably" pre-dates the schism.

\section{THE PRIVILEGE OF EUFRASIUS}

The Privilege of Eufrasius (henceforth $P E$ ) is cited in the entry on Eufrasius in the $P C$ but with a caution about its containing later interpolations. The extant $P E$ is a seemingly "authentic" early modern copy of a document claiming to be the renewal by the thirteenth century Parentine bishop, Adalpert, of the "original" $P E$ which Adalpert claims had been renewed by all of Eufrasius's successors, whose names he lists ${ }^{55}$. The opening paragraph explains that Adalpert is renewing the $P E$, after which the text of the "original" begins: "With Flavian ruling as emperor of the Romans, triumphant augustus, in the $16^{\text {th }}$ year of his reign, on the $24^{\text {th }}$ day of the month of March, in the $6^{\text {th }}$ indiction" 56 . The Eufrasius who is the initial recipient of the privilege is presumably the one depicted in the central apse mosaic, so the emperor would be Justinian, but the document names a Flavianus. Justinian, however, took the name Justinian when he was adopted by his uncle, emperor Justin I. He was born Flavius Petrus Sabbatius. Assuming that this refers to Justinian, then the date is unambiguously the year 543. Justinian's coronation was in 527 , the document refers to the sixteenth year of a reign, and the year 543 is a sixth indiction year. Terry and Maguire only mention the $P E$ in a footnote ${ }^{57}$, where it is dismissed on the authority of Picard as "spurious" and a Carolingian-era forge$\mathrm{ry}^{58}$. Picard, however, in his encyclopedic work on episcopal lists, writes the following: "On January 23, 1222, the bishop of Poreč [Parentium] Adalpert confirmed a privilege of his long ago predecessor Eufrasius, dated March 24, 543, of which he inserted the text into his own document. This privilege ["his own document"] established in favor of the canons of the cathedral of Poreč is a fake, fabricated according to all appearances by the canons themselves" 59 . A careful reading, I believe, shows that Picard considers the thirteenth century document, "established in favor of the canons", to be a fake, but that its medieval Istrian inventor inserted a text of 543 into his later document (dont il insère le texte dans son propre acte). Regarding the list of the bishops of Parenzo/Poreč, Picard believes the thirteenth century author "constructed his list himself by utilising the documents that he was able to find in the archives of the cathedral and which served him at the same time as guarantees. One can only hope that the names which are unknown to us [from other sources] have been truly taken from authentic documents"6o. Rather than dismissing the $P E$ as spurious, then, Picard uses it as a source, confirms the accuracy of the names that are known to us from other sources, and "hopes" that the rest are also correct. In so doing, he concedes a kernel of authenticity to an "original" $P E$.

The year 543 itself is a strong indicator of such authenticity. The year is not given directly but as "in the $16^{\text {th }}$ year of his reign ... in the $6^{\text {th }}$ indiction". We know this is 543 because we know the year of Justinian's coronation (527) and that 543 is a sixth indiction year. Would a thirteenth century Istrian, either a bishop or a canon, inventing the $P E$ out of whole cloth, know how to make this up? Granting that he did, he would still have to choose the year 543 in the first place. But out of the 38 years of Justinian's reign [527-565], how did a medieval Istrian manage to pick the optimal year that a well-informed modern forger would use in order to make the document appear authentic? Years before 540 would appear to be suspicious, as it was only in that year that Ravenna, along with the Gothic king Witiges, was captured by Belisarius, the Gothic War seemingly won. But 540 also saw one of the great disasters of Justinian's reign, the destruction of Antioch by the Persians. Belisarius was recalled from Italy partly to deal with the Persians, opening the door for a Gothic resurgence under Totila in 541.542 was the year of the plague, Justinian himself barely surviving the plague $^{61}$. Unlike the disastrous years of 540 to 542, 543 and 544 were years of recovery and new beginnings. Price argues that the disasters of the early 540 explain Justinian's subsequent religious policies; obviously, God was displeased ${ }^{62}$. In 543 Justinian condemned Origen, and the campaign to condemn the Three Chapters, which would culminate with Constantinople II in 553, had begun by 544. In 544 Belisarius was sent back to Italy to confront Totila. 543 is the perfect year to pick for a credible forgery. As to whether a medieval Istrian could make such an informed choice, consider Agnellus of Ravenna, writing in the first half of the ninth century. In his entry on bishop Ursicinus [533$536]^{63}$, out of nine events mentioned, six actually occured after 536, and the three events involving Belisarius are out of sequence. In the entry on bishop Maximian, Agnellus of Ravenna has Pelagius I die when Maximian is bishop, while in fact Pelagius becomes becomes bishop of Rome about the time Maximian dies ${ }^{64}$. A medieval churchman writing four centuries later in an Istria that had long been absorbed

\footnotetext{
55 The best source for the PE, which includes the text, is still B. BENUSSI, Privilegio Eufrasiano, in Atti e Memorie della società istriana di archeologia e storia patria, 28, 1892, p. 49-86.

${ }_{56}$ "Imperante Flaviano Romanorum imperatore triumphatore Augusto Anno Imperij eius XVI die vero XXIIII mensis martij Indictione VI ...." as found in BENUSSI, Privilegio, p. 49.

57 TERRY, MAGUIRE, Dynamic Splendor, 1, p. 196, fn. 1.

${ }^{58}$ J.-C. PICARD, Le souvenir des évêques. Sépultures, listes épiscopales et culte des évêques en Italie du Nord des origines au Xe siècle, Rome, 1988, p. 477-480. 59 The original text in Picard is: Le 23 janvier 1222, l'évêque de Poreč Adalpert confirme un privilège de son lointain prédécesseur Eufrasius (...558/559...), daté du 24 mars 543, dont il insère le texte dans son propre acte. Ce privilège, établi en faveur des «chanoines» (!) de la cathédrale de Poreč est un faux, fabriqué selon toute vraisemblance par les chanoines eux-même.

${ }^{60}$ PICARD, Le souvenir, p. 480

${ }^{61}$ For these "catastrophes" see A. KALDELLIS, Procopius of Caesarea: Tyranny, History, and Philosophy at the End of Antiquity, Philadelphia, 2004, p. 204-213.

${ }^{62}$ PRICE, The Acts, 1, p. 15-16.

${ }^{63}$ Agnellus of Ravenna, LPR, 178-181.

${ }^{64}$ Ibid., 193.
} 
by the Holy Roman Empire could hardly have been better informed about the Roman Empire in late antiquity than Agnellus of Ravenna.

It was the nineteenth century Istrian scholar, Benussi, who identified the anachronisms in the $P E$ inconsistent with a sixth century document, which therefore betray later interpolations. He posits a thirteenth-century conflict between the pretensions of an emerging commune (comune) of Parentium and the traditional authority of the episcopate to explain the "fabrication" of the "new privilege". In the thirteenth century Adalpert "modified an already extant Privilege of Eufrasius interposing that which he was interested to establish against the pretensions of the Parentine commune" ${ }^{65}$. While "the new Privilege of Eufrasius was fabricated" in the thirteenth century, "of the content ... which has come down to us, the following may be trustworthy: on May 24543 there was held at Parentium a solemn meeting of the envoys of the emperor Justinian, together with the bishop Eufrasius, the magister militum, the clergy and the people of Parentium to establish the rights and recipricol obligations between the episcopal church and the inhabitants of the town and territory with respect to the tithe"66. Accepting Benussi's conclusions establishes Eufrasius as bishop in Parentium by $543^{67}$. Together with the inscription on the Altar of Eufrasius, which states that the church was consecrated in the eleventh year of his episcopate ${ }^{68}$, the $P E$ furnishes a terminus ante quem for completion of the church of 554, placing the project within Maximian's reign as bishop of Ravenna [546-556], before any schism, and more in line with the sculptural evidence presented by Terry and Maguire. Imperial concern for Parentium together with the establishment of the Parentine episcopacy on a sound financial footing, both evidenced in the $P E$, explains how the resources could be mobilized, both at the imperial and local levels, to undertake such a monumental project as the Parentine episcopal complex, which still stands to this day.

\section{IMPERIAL RECONQUEST AND RENEWAL, CHURCHES OF THE MOTHER OF GOD}

The context for the church of San Mauro is Justinian's reconquest of the eastern Adriatic -Dalmatia, Liburnia, and Istria. Procopius says relatively little about the region in Gothic War because the war was won there immediately. Justinian's first act of the war was to command "the general of Illyricum to go to Dalamatia, which was subject to the Goths, and make trial of Salona"69. After an initial setback, Constantianus "gained possession of all Dalmatia and Liburnia ..., the winter drew to a close, and thus ended the first year [535] of this war"7o. The eastern Adriatic was subject to occasional raids, but it was never again seriously threathened by the Goths. When Belisarius is sent back to Italy in 544, he winters at Pola in Istria, where Totila sends spies to ascertain his strength ${ }^{71}$. When Narses returns in 551 with the army that will defeat Totila, Salona is the staging area. Rather than sail the army across the Adriatic, Narses leads it up through Dalmatia and Liburnia, and across Istria, without incident. Only in Venetia, infested with Franks, does Narses "find himself completely bewildered". John [the Patricius], the nephew of Vitalian, "being familiar with these regions", advised him to proceed along the coast, "the inhabitants of this region ... being subject to [the Romans]", and "whenever they should come to the mouth of a river, ... throw a bridge of boats across the river's current"72. And so Narses made the journey to Ravenna with the whole army.

In Buildings Procopius writes that "The Emperor Justinian built many churches to the Mother of God in all parts of the Roman Empire"73. For reasons unknown, the geographical coverage of Buildings goes no farther north and west than Illyricum, and Procopius himself admits that "there are many which I have omitted to mention," but he mentions seven which are outside of Constantinople ${ }^{74}$. In Antioch after Persian destruction Justinian built a "great Church of the Mother of God"75. In Jerusalem the monumental Nea Church is a shrine to the Mother of God "with which no other can be compared" 76 . In the Sinai, at what is today called St Catherine's Monastery, in addition to this church dedicated to the Mother of God, Justinian "built a very strong fortress ... in order that the barbarian Saracens might not be able ... to make inroads ... into the lands of Palestine proper" 77 . At Carthage Justinian built a shrine to the Mother of God and rebuilt "the whole circuit-wall, which had fallen down"78. Leptis Magna "he has surrounded with a very strongly built wall. Here he dedicated to the Mother

\footnotetext{
${ }^{65}$ See BENUSSI, Privilegio, p. 83-84.

${ }^{66}$ Ibid., p. 74 .

${ }^{67}$ Eufrasius may have been installed in 543 replacing the former "Gothic" bishop.

${ }^{68}$ Sotinel cites Cuscito for her statement that bishop Eufrasius built the church as a Three Chapters schismatic. See C. SOTINEL, The Three Chapters and the Transformation of Italy, in The Crisis of the Oikoumene, 106, fn. 81. Cuscito's evidence is the inscription on the Altar of Eufrasius which states that the church was consecrated in the eleventh year of his episcopate. Cuscito's “Three Chapters" argument is based on the presence of the single word, catholec (ae), in the inscription; others have argued that this misspelling of the Latin word, catholicae, is a graecism revealing its carver to have been a Greek speaker, evidence for imperial involvement! See G. CUSCITO, Testimonianze epigrafiche sullo scisma tricapitolino, in Rivista di archeologia cristiana, 53, 1977, p. 235-36. For the alternative interpretation, G. BOVINO, Le antichità cristiane della fascia costiera istriana da Parenzo a Pola: Testo, Bologna, 1974, p. 15. While Terry and Maguire include a photo of the Altar of Eufrasisus, it is not mentioned in their text.

${ }^{69}$ Procopius, Gothic War, 3, 43.

$7^{70}$ Procopius, Gothic War, 3, 69.

${ }^{71}$ Procopius, Gothic War, 4, 233-235.

${ }^{72}$ Procopius, Gothic War, 5, 337.

73 Procopius of Caesarea, Buildings, in Procopius, VII, 39.

74 Ibid.

75 Ibid., 173 .

${ }^{76}$ Ibid., 343.

77 Ibid., 355-357.

${ }^{78}$ Ibid., 381.
} 
of God a very notable shrine"79. At the Pillars of Heracles, Septum [Ceuta], "being neglected by the Vandals ... [and] destroyed by time", Justinian "made it strong by means of a wall", a church of the Mother of God was consecrated "thus dedicating to her the threshold of the Empire, and making this fortress impregnable for the whole race of mankind"8o.

The cult of Theotokos emerges in Buildings as intimately linked with Justinian's imperial and urban renewal and the defense of the empire, particularly in reconquered areas. With the exception of St Catherine's in Sinai, the structures described by Procopius in what became the Arab world and Turkey have either vanished or are archeological excavations, but we can still see one such today, the episcopal complex at Parenzo/Poreč (Parentium). A stone's throw from the Adriatic Sea (fig. 1), it includes the basilica of San Mauro with its Theotokos central apse mosaic, as well as a baptistry and a bishop's residence. It is a mini-"Sacred Fortress", inconceivable without the town's circuit wall for protection ${ }^{81}$. Eufrasius's dedicatory inscription says the church was falling down and had to be rebuilt, but this would then likely have applied to the walls and town fortifications as well. At Salona, Procopius notes in Gothic War how "Constantianus proceeded to look after the fortifications of the city, building up in haste all such parts of them as had fallen down" under Gothic rule ${ }^{82}$. In Buildings, Procopius documents the same for an Africa "neglected by the Vandals".

Churches of the Theotokos anchored Justinian's imperial and urban renewal and defense policies because Theotokos was central to his religious policy, and all three were intertwined. Price argues that the campaign to posthumously condemn both Origen and the most important of the "Three Chapters", Theodore of Mopsuestia, which culminates in Constantinople II, grew out of the disasters of 540-542, seen by a devout Justinian as a sign of God's displeasure ${ }^{83}$. More cynical observers have long interpreted his religious policy as a desperate political ploy to achieve unity in the imperial church by appeasing those who had rejected Chalcedon ${ }^{84}$. In any event, the condemnation of Theodore of Mopsuestia, the teacher of Nestorius, and the affirmation of the ever-virgin Mary as Theotokos are two sides of the same coin. The condemnation of Nestorius in 431 at the Council of Ephesus was also the affirmation of the ever-vigin Mary as, literally, the Mother of God, in the form of the Word made flesh, the second person of the Trinity, as emphasized by Patriarch Cyril of Alexandria. Chalcedon undertook the new business of condemning the "Monophysite", Eutyches, but it also reaffirmed the doctrine of Theotokos and the condemnation of Nestorius, albeit in a deeply flawed way in the opinion of those who rejected it. Canon 6 of Constantinople II explicitly links the condemnation of Theodore and the affirmation of Mary as Theotokos ${ }^{85}$ :

6. If anyone says that it is ... not truly that the holy and glorious ever-virgin Mary is Theotokos ... since a mere man was born [from her] ... the birth of the man having reference, according to them, to God the Word as being with the man who was being born, and misrepresents the holy council at Chalcedon as having called the Virgin Theotokos according to this impious interpretation thought up by [the execrable] Theodore, or if anyone ... does not profess that she is really and truly Theotokos because God the Word, born from the Father before the ages, was in the last days incarnate and born from her ... let him be anathema (Canons of the Council of Constantinople II).

The fundametal significance of Theotokos derives from her being the vehicle for the incarnation of God the Word. Justinian's "revisionist", "moderate neo-Chalcedonianism", which he was able to impose at Constantinople II, is imbued with an Alexandrine, Cyrillian emphasis on the oneness of Christ, the "one incarnate nature of God the Word" in Cyril's favored expression ${ }^{86}$. Canon 8 states it thusly: "from the divine and human natures, after the hypostatic union, one Christ was constituted ... Consequently there is but one Christ God and man, the same consubstantial with the Father in respect of the Godhead and the same consubstantial with us in respect of the manhood"87. The significance of the incarnation is the Economy of Salvation: the incarnate God the Word, the Son, literally dies on the cross for human redemption. Canon 1o succinctly states the theopaschism that Justinian had embraced from his earliest days as emperor $^{88}$ : "If anyone does not profess that our Lord Jesus Christ, crucified in the flesh, is true God and Lord of glory and one of the holy Trinity, let him be anathema"s9.

\section{MOSAIC ICONOGRAPHY}

San Mauro is a three-apsed basilica, an originally SyroPalestinian architectural church form that won't appear in Rome until the eighth century, during the time of the "Greek" popes ${ }^{\circ}$. Both architecturally and iconographically, San Mauro may be closer to the three-apsed Church of Saint Sergius in Gaza, from the 530s, than to those in Ravenna. The ekfrasis of Choricius of Gaza preserves much information about this church, long since disappeared and not mentioned by Procopius ${ }^{91}$. As at San Mauro, the central

\footnotetext{
79 Ibid., 375-377.

${ }^{80}$ Ibid., 391-393. Having reached the Straight, this is Procopius's grande finale in Buildings.

${ }^{81}$ I allude to the classic work on Ravenna of Otto Georg Von Simson. Curta notes that the archeological record for the urban Balkans in the age of Justinian shows an emphasis on defensible cities anchored by churches. See F. CURTA, Southeastern Europe in the Middle Ages: 500-1250, Cambridge, 2006, p. 39-53.

${ }^{82}$ Procopius, Gothic War, 3, 69.

${ }_{3}$ PRICE, The Acts, 1, p. 15-16.

${ }^{84}$ For Justinian's religious policy see Price, The Acts, 8-42 and GRILLMEIER, Christ in Christian Tradition, p. 317-473.

${ }_{5}$ PRICE, The Acts, 2, p. 121-122.

${ }^{86}$ For Justinian's Cyrillian infused, moderate neo-Chalcedonianism, see GRILLMEIER, Christ in Christian Tradition, p. 429-439.

${ }^{87}$ PRICE, The Acts, 2, p. 121-122.

${ }^{88}$ Theopaschism is discussed in GRILLMEIER, Christ in Christian Tradition, p. 317-343.

${ }^{89}$ PRICE, The Acts, 2, p. 121-122.

${ }^{90}$ See R. KRAUTHEIMER, Rome: Profile of a City, 312-1308, Princeton NJ, 1980, p. 89-108.

${ }^{91}$ A French translation and discussion is provided in F.-M. ABEL, Gaza au VIe siècle d'après le rhéteur Chorikios, in Revue Biblique, 1931, p. 5-31. See also G. DOWNEY, Gaza in the Early Sixth Century, Norman, 1963, p. 117-139.
} 


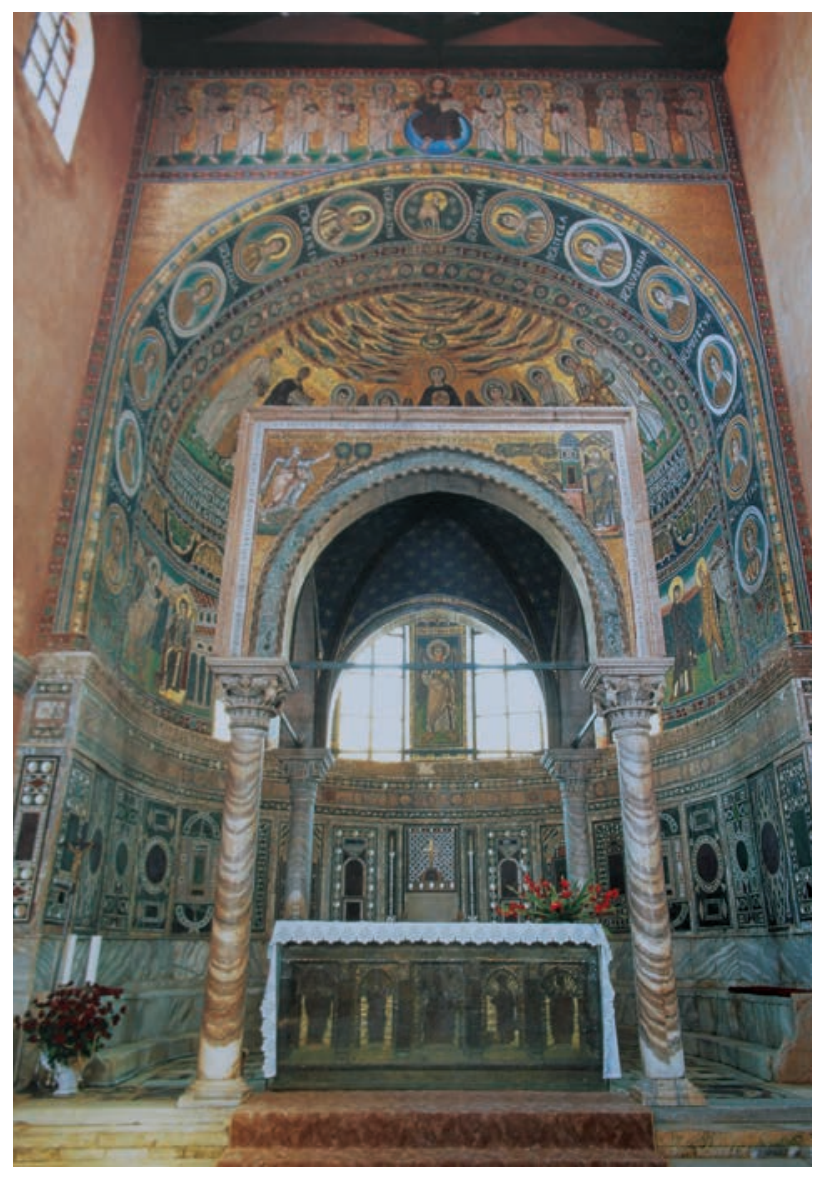

Fig. 6: Triumphal arch. Central apse in three registers: 1) semi-dome; 2) four windows, three piers and two side-wall wings; 3) solid wall with opus sectile and marble benches. $13^{\text {th }}$ century Venetian ciborium over main altar blocking view. Church of San Mauro. Parenzo/Poreć (Parentium).

image of the central apse is Theotokos, the virgin Mary enthroned holding the Christ child, with groups of figures to both sides. The governor of Palestina Prima, Stephanus, is depicted on the right presenting a model of the church to its patron saint, Sergius, who in turn will present the governor to "the Virgin and her Son the Savior"92. There is a suggestion that the bishop, Marcianus, who "shares his [Stephanus's] labors" in building the church, is also depicted in the mosaic ${ }^{93}$. Expect for being on the right side rather than the left, this is essentially the same composition as at San Mauro where it is Eufrasius, accompanied by his deacon, who holds the model of the church and who will be presented by Saint Maurus to Theotokos (fig. 3); so the Parentine bishop, Eufrasius, and the Gazan governor, Stephanus, are depicted in exactly the same way in these Justinianic churches of the Theotokos, with the implication that the bishop is every bit the imperial official as the governor. In 536, Justinian raised the status of the governor of Palestina Prima to proconsul and promoted Stephanus to the new position ${ }^{94}$. We also know that Stephanus "carried out a programme of building works at Gaza where he restored the city wall", and that he "suppressed Egyptian brigands ... and marauding Saracens" 95 . As at Parentium and the locations mentioned by Procopius in Buildings, there

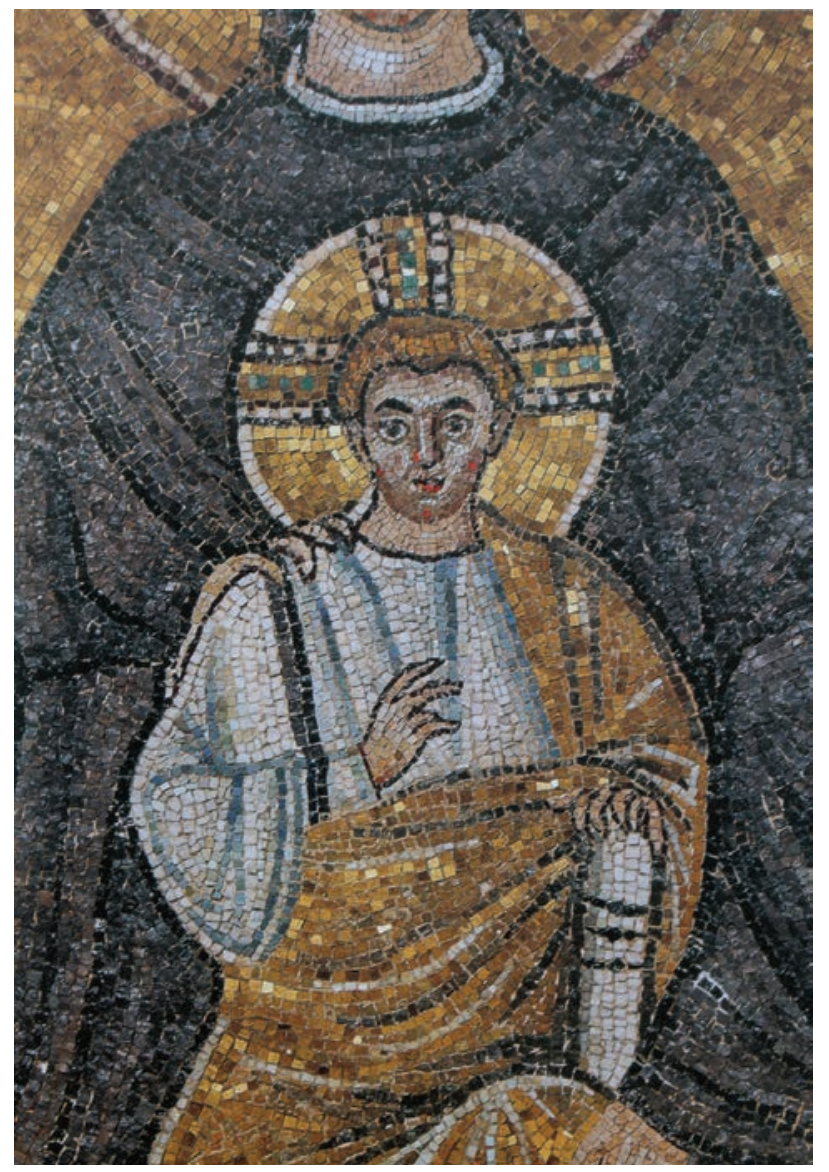

Fig. 7: Central image of central apse mosaic: The Word made flesh. "From the divine and the human natures, after the hypostatic union, one Christ was constituted." Canon 8, Constantinople II. Church of San Mauro. Parenzo/Poreč (Parentium)

is the same combination of imperial and urban renewal, the strengthening of walls and defenses, and the building of churches connected to Theotokos. A direct connection between $V \mathcal{E} H$ and the now Middle East in this period is provided by Agnellus of Ravenna who includes, in his entry on Maximian, a long quote from a lost work of Maximian that describes his lengthy sojourn in Egypt, from where he would have certainly travelled to the Holy Land ${ }^{96}$.

The architecture of the east end of San Mauro is a triumphal arch framing a vault with a central apse in three registers, flanked by two side apses (fig. 6). The upper third of the central apse is a semi-dome, beneath which is a middle third with four elongated semi-oval windows separating three piers, leaving two larger curving wall surfaces at the two extremes. The lower third is a solid curving wall extending to the floor. The mosaic figural decoration of this space follows a hieratic pattern in three descending registers: the flat surface extending across the top of the arch; the upper third semi-dome of the apse itself; and the middle third with alternating windows and piers and the apse wall on the two wings. The lowest third of solid curving wall is decorated in non-figural opus sectile above and, at the lowest level, there is the marble bench for the canons with the bishop's cathedra in the center.

\footnotetext{
${ }^{92}$ DOWNEY, Gaza, p. 128.

${ }^{93}$ Ibid.

${ }^{94}$ See STEPHANUS 10, The Prosopography of the Later Roman Empire (Cambridge: Cambridge University Press, 1971), 1184-85.

95 Ibid.

${ }^{96}$ Agnellus of Ravenna, LPR, 193-197.
} 


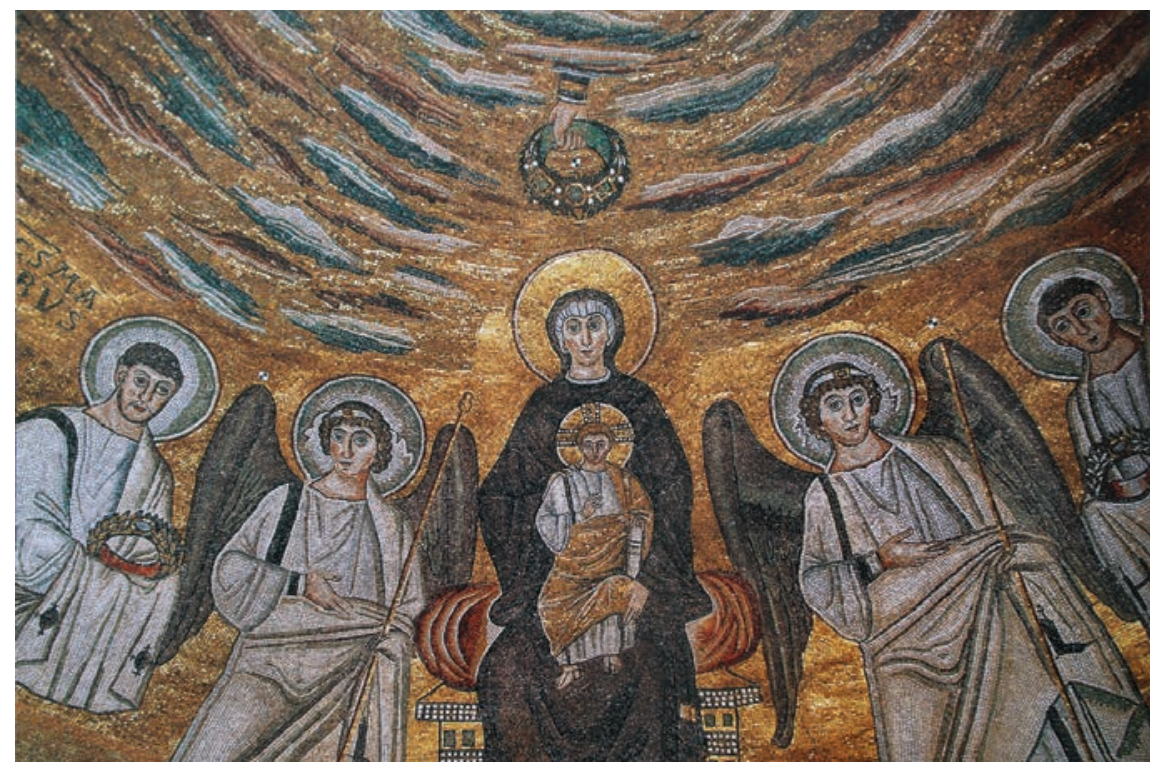

Fig. 8: Theotokos. "God the Word, born from the Father before the ages, was in the last days incarnate and born from her." Canon 6, Constantinople II. Church of San Mauro. Parenzo/Poreč (Parentium).

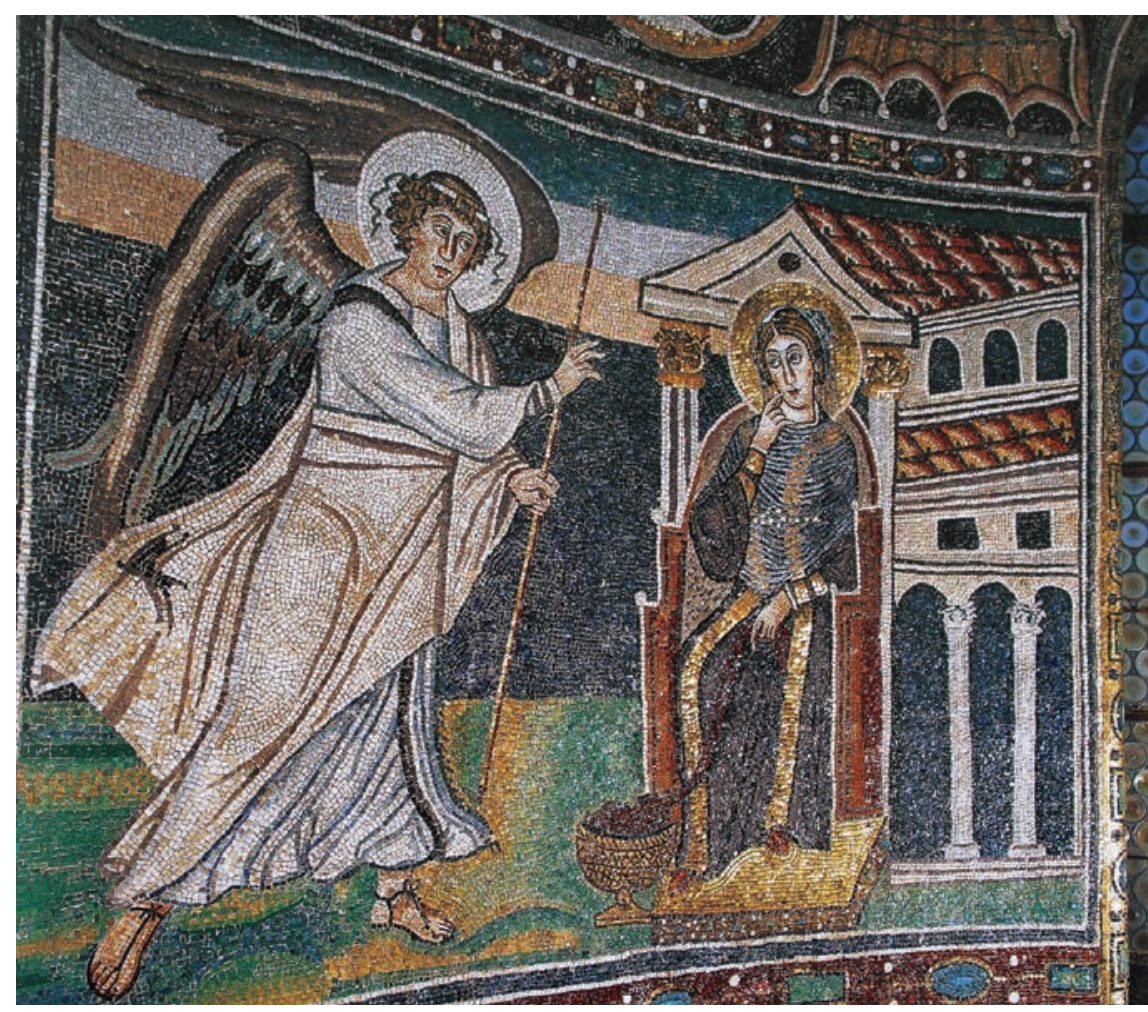

Fig. 9: The Annunciation. Virgin Annunciate spinning purplelred thread.Church of San Mauro. Parenzo/Poreć (Parentium)

At the top, at the center of the triumphal arch (fig. 2), is a beardless Christ all-powerful - Christus omnipotens or

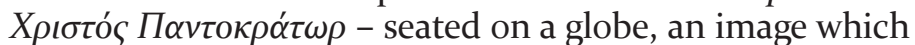
is virtually the same, right down to hair style, costume and color, as that in the apse at San Vitale. Christ is flanked by two sets of six apostles, beginning with Peter on his right and Paul on his left. The central image of the central apse, directly below this Christ, is the virgin Mary seated on a throne and, seated on her lap, not a "baby Jesus", but the Christ child, looking like a miniature adult (fig. 7). Both images of Christ are nimbused with a Greek cross-inscribed halo, and both

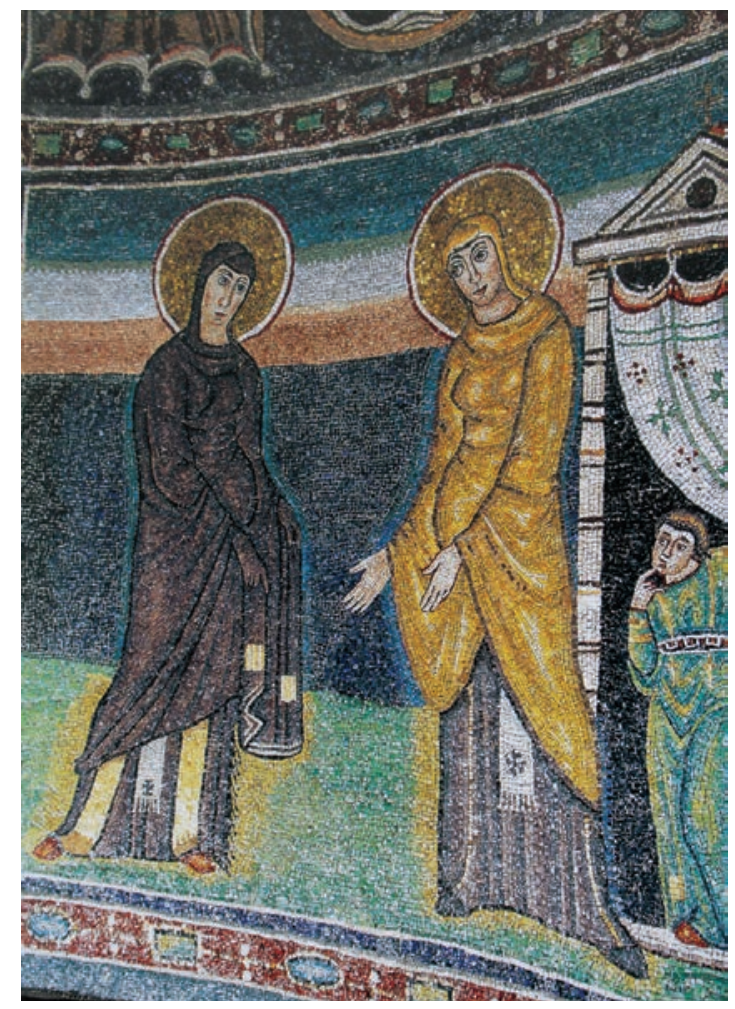

Fig. 10. The Visitation. Mary and Elizabeth visibly pregnant. Church of San Mauro. Parenzo/Poreč (Parentium).

give a similar gesture with the right hand. The Christ child holds a closed book in his left hand. The Christ above holds an open book that reads, "EGO SUM LUX VERA". So the Christ child that Mary holds is identified completely with the Christ above.

Emerging from the heavens which form the background of the apse mosaic is a hand holding a wreath over Mary and the Christ child (fig. 8). They are flanked on each side by an angel and, on the left, by Saint Maurus who leads Eufrasius, holding a model of the church, et al., and, on the right, by three other unidentified saints (fig. 2). Below the semi-dome on the third mosaic register, or the middle third of the apse, there are two distinct types of representations. Those on the three piers are directly below the semidome of the apse, while those on the apse wall to the extreme left and the extreme right are out from under the semi-dome. On these two outer wings there is the beginning of a temporal, historical, scriptural narrative.

On the far left, Gabriel announces to Mary, a virgin, that she will conceive, or has in fact just done so (fig. 9). The virgin Annunciate is holding the red/purple thread which comes from the basket at her feet, so this is as much the Mary of the Protevangelium of James ${ }^{97}$ as of the Gospel of Luke. The literary description of the scriptural narrative on the ceiling at Saint Sergius by Choricius begins similarly: "A winged being has just descended from heaven", and "startled by the unexpected vision, [Mary] nearly lets fall the purple [thread] from her hand"98. On the side wall opposite the Annunciation is the Visitation (fig. 10); the Precursor, John,

\footnotetext{
${ }^{97}$ An English translation of the Protevangelium can be found in Bart D. EHRMAN, Lost Scriptures: Books that Did Not Make It into the New Testament (Oxford: Oxford University Press, 2003) 63-72.

${ }_{98}^{8}$ DOWNEY, Gaza, 128.
} 


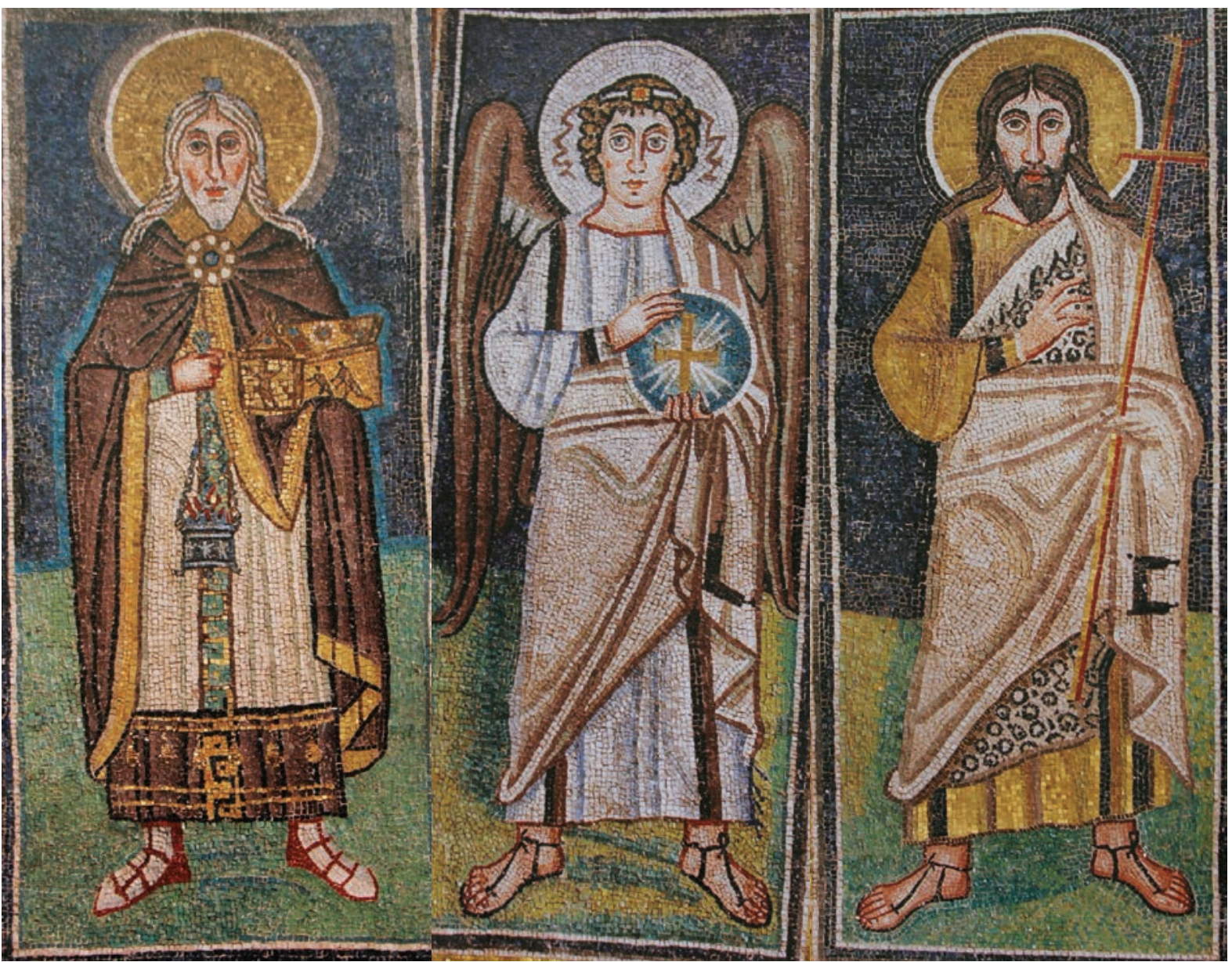

Fig. 11. Figures on piers of central apse mosaic: Zacharias, angel (Archangel Michael?), John the Baptist. Church of San Mauro. Parenzo/Poreč (Parentium).

invisibly prophesies from the womb of a visibly pregnant Elizabeth the coming birth of the Redeemer, present in the womb of a visibly pregnant Mary. In the Visitation scene at Saint Sergius, Mary goes "to visit a kinswoman and friend, and is about to tell her what has happened; the latter anticipates her through premonition and falls on the maiden's breast" 99 . Choricius then goes on to describe scene after scene, many from Luke, some uniquely so, culminating with the Passion and Resurrection. At San Mauro only the apse mosaics remain, and the narrative ends with the Visitation.

Between Annunciation and Visitation, directly under the semi-dome, there are full-figure, full-frontal portraits on three piers separated by four windows (fig. 11). On the central pier, an angel (the Archangel Michael?) holds an orb within which is inscribed a Greek cross. Flanking him are, to his left, John the Baptist - the Precursor - and to his right, Zacharias, priest, prophet, and father of the Precursor in the Gospel of Luke and, in the Protevangelium of James, martyred by Herod at the time of the slaughter of the innocents ${ }^{100}$. His censor and incense casket ${ }^{101}$ evoke the annunciation by Gabriel at the Jerusalem Temple that he and Elizabeth will conceive a child to be named John, as found uniquely in Luke. Zacharias and John are each represented at their respective ages of martyrdom, so this is not historical narrative. Standing directly beneath the semi-dome of the apse, they are now heavenly, prophetic witnesses to the infinite and eternal divine mystery - the incarnation - represented above them.

The central image of the central apse mosaic (fig. 8) can be read as a visual statement of the doctrine expressed in Canon 6 of Constantinople II: "God the Word, born from the Father before the ages, was in the last days incarnate and born from her". The image is, in a word, Theotokos, the Mother of God and her divine progeny - the incarnate Logos, the Word made flesh, the Second Person of the Trinity, the one Lord and Saviour, Jesus Christ. Mary is not holding a "baby Jesus" who will grow up to be the man from Galilee. There is no suggestion of an Antiochene/Theodorian/ Nestorian view of Jesus as the man within whom the Logos takes up residence. Rather, we see the result, affirmed in Canon 8 of Constantinople II, that "from the divine and the human natures, after the hypostatic union, one Christ was constituted"102 (fig. 7). Extolling Theotokos and the oneness of Christ, this image implicitly condemns both Nestorius and Theodore.

In the north apse, the same Christ who appears on the arch holds martyrs' wreaths over the heads of Saints Cosmas and Damian (fig. 12). In the center of the central apse, the hand of God (the Father) holds a similar wreath above Mary and (God) the Son (fig. 8). Directly below the center of the central apse, on the lowest, most earthly, level, which

\footnotetext{
99 Ibid.

${ }^{100}$ This comes at the end of the Protevangelium.

${ }^{101}$ I interpret the figural scene represented on the incense casket as the Flight of Elizabeth from the Protevangelium.

${ }^{102}$ Canon 8 of Constantinople II, Price, The Acts, 2, 123. This is distinctly Cyrillian. For Justinian's "moderate" neo-Chalcedonianism, with its qualified adherence to Cyril of Alexandria, see GRILLMEIER, Christ, 433-48.
} 


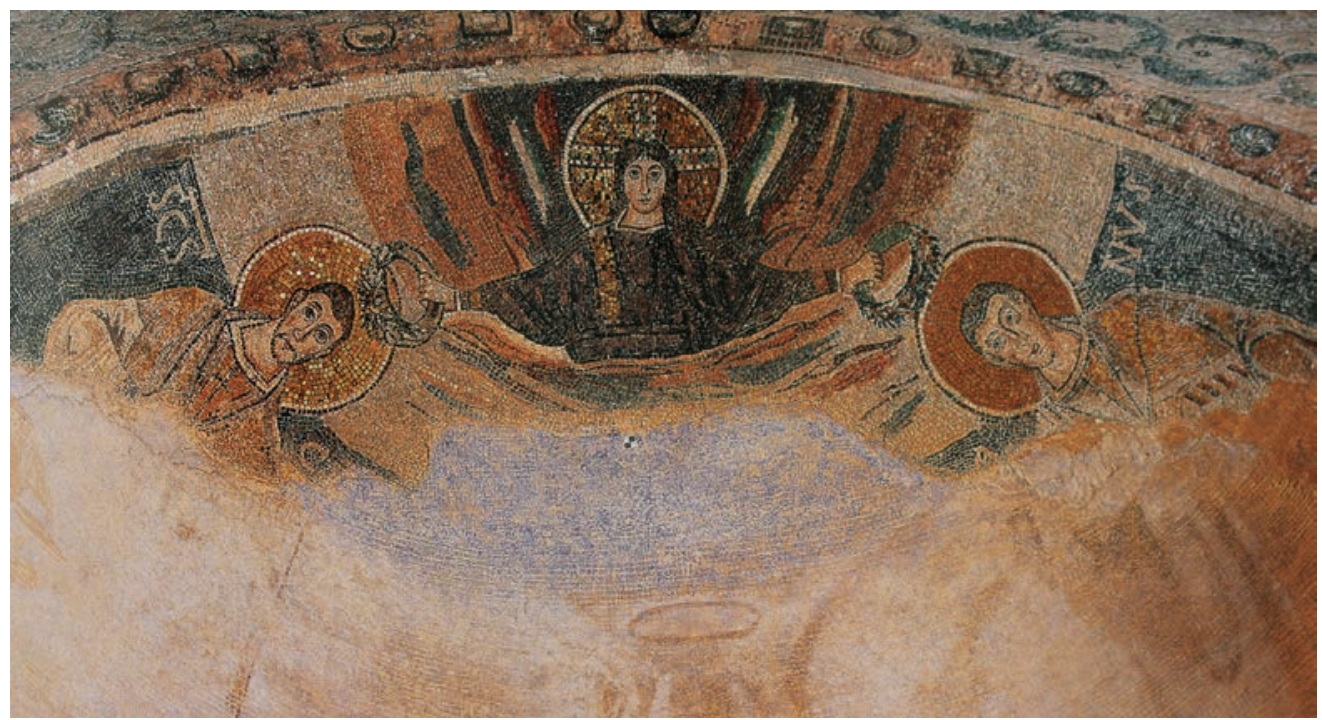

Fig. 12: North Apse, Cosmas and Damian receiving martyrs' wreaths from Christ. Church of San Mauro. Parenzo/Poreč (Parentium).

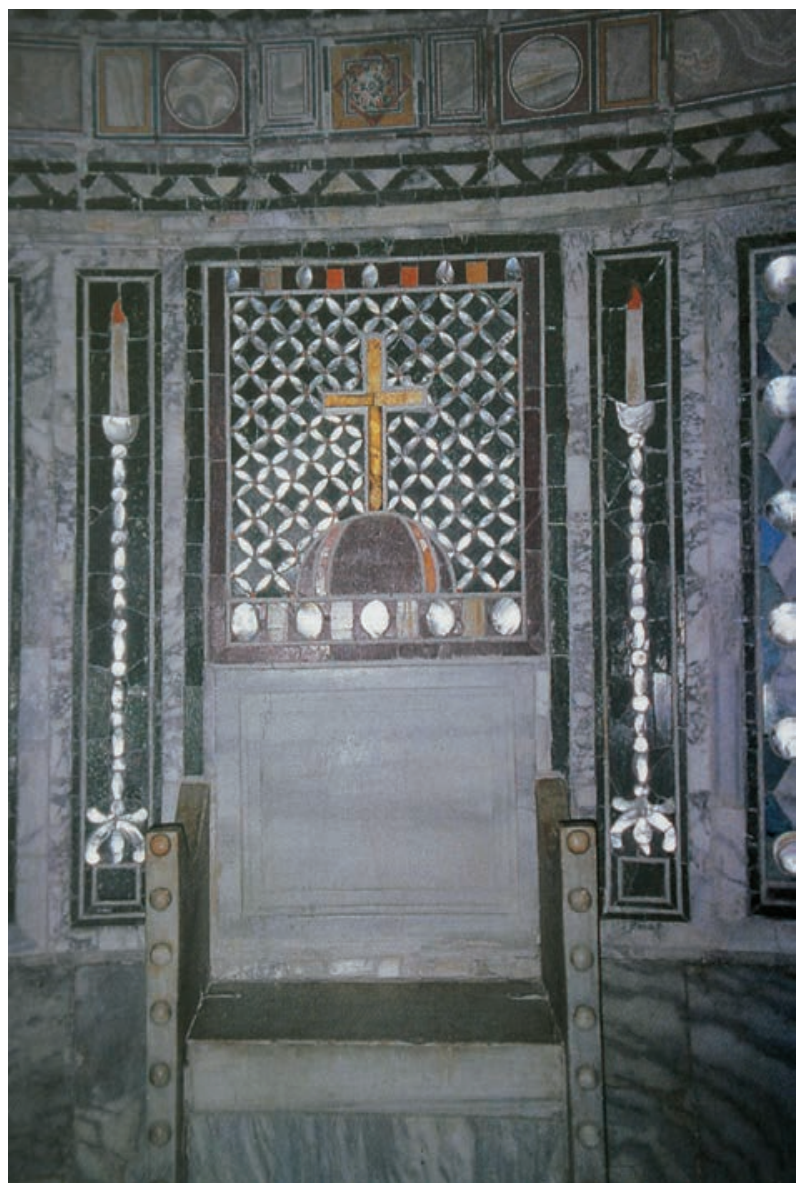

Fig. 13: Bishop's cathedra and opus sectile cross, directly beneath the central Apse. Church of San Mauro. Parenzo/Poreć (Parentium).

is decorated in opus sectile, there is a cross just above the bishop's cathedra (fig. 13) ${ }^{103}$. If we understand God the Father, nowhere figurally represented other than by the hand that emerges from the heavens, to be presenting the martyr's wreath to the Son, then this tripartite ensemble of (wreath/ incarnate-Logos/cross) (fig. 14) constitutes a visual statement of the so-called Theopaschite Formula - "One of the Trinity suffered in the flesh"104. Canon 10 of Constantinople II

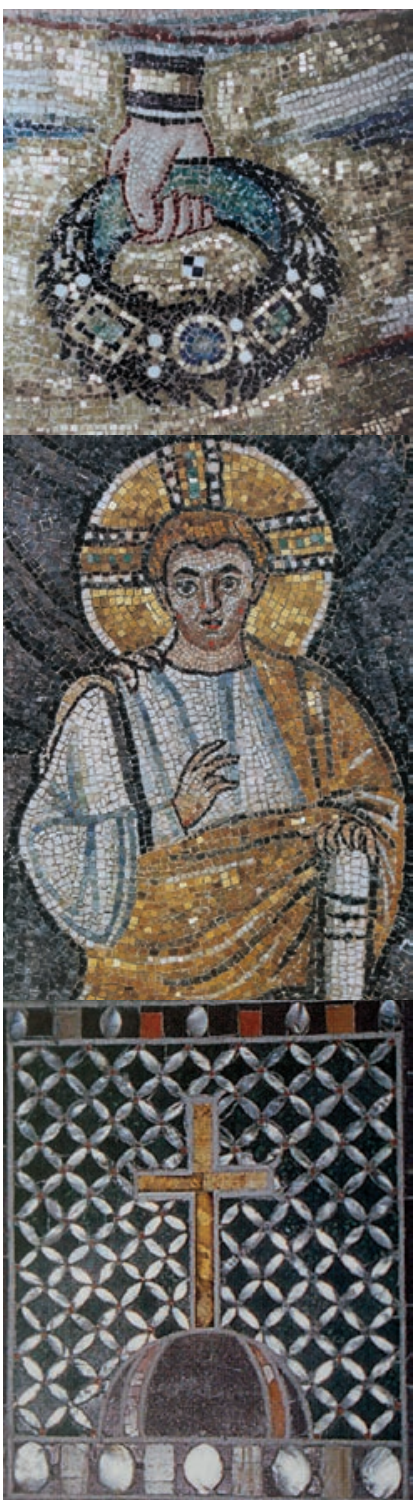

Fig. 14: Theopaschite Formula. "Our lord Jesus Christ, crucified in the flesh, is ... one of the holy Trinity." Canon 10, Constantinople II. Church of San Mauro. Parenzo/Poreć (Parentium).

${ }^{103}$ I am indebted to Terry and Maguire, who point out the alignment and significance of this combination of images but do not give them a Theopaschite interpretation. See TERRY and MAGUIRE, Dynamic Splendor, $1,73$.

${ }^{104}$ Author's emphasis on the one. Rome tended to frown upon the Theopaschite Formula of the Scythian monks as tainted by "monophysitism," but it was endorsed by Pope John II ("Mercury"). See JOHN II in J.N.D. KELLY, The Oxford Dictionary of Popes, Oxford, 1986, p. 57-58. 
expresses it thusly: "If anyone does not profess that our Lord Jesus Christ, crucified in the flesh, is true God and Lord of glory and one of the holy Trinity, let him be anathema"105. This vertical arrangement is not temporal, or historical, narrative, like the horizontally and temporally arranged Annunciation and Visitation on the two wings below the semi-dome of the apse. The center of the central apse is not at Bethlehem; this is not a Nativity. The image represents a theological doctrine out of time and space, an infinite and eternal divine mystery, the Incarnation (with Crucifixion, Resurrection and Salvation implied). The vertical axis of the infinite and eternal within the apse extends from the hand of God emerging from the heavens, through Theotokos, down to the cross at the lowest, earthly level; the horizontal axis below the semi-dome is a historical, temporal narrative of Annunciation and Visitation, bookending the prophetic witnessing of Zacharias and John. Their intersection, the intersection of the eternal and infinite with the

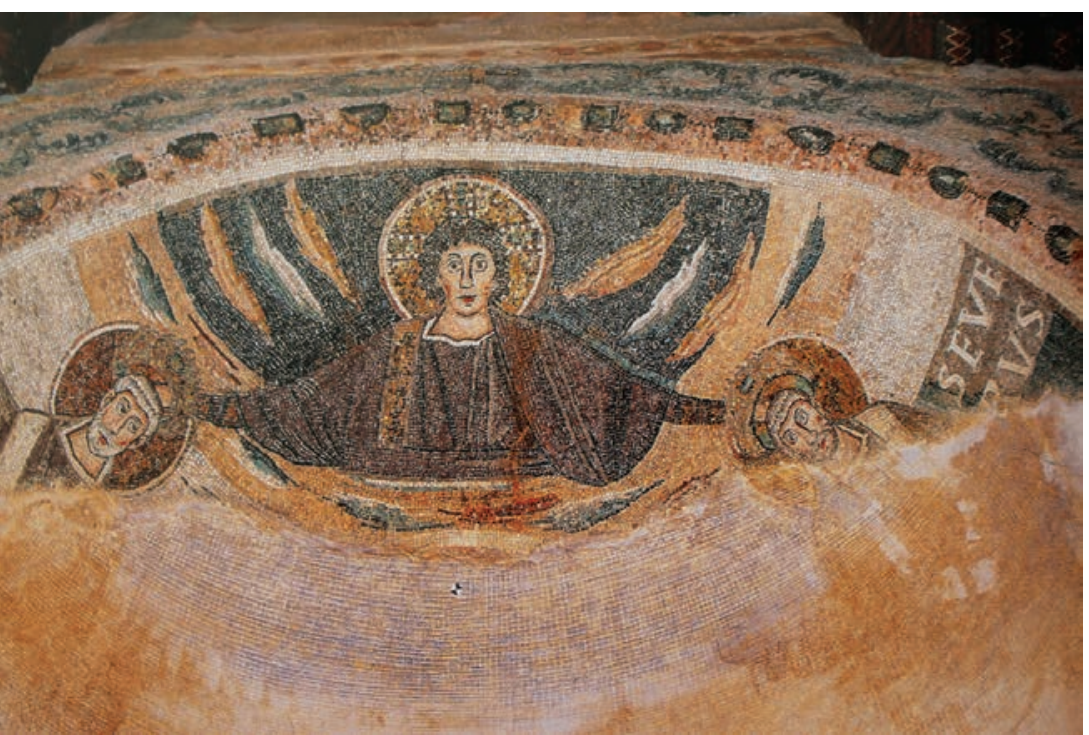

Fig. 15: South Apse, bishops Hermagoras of Aquileia (left) and Severus of Ravenna (right). Church of San Mauro. Parenzo/Poreč (Parentium).

piety with respect to Cosmas and Damian with the policy of urban and imperial renewal, and building that wall!

In the south apse (fig. 15), Christ presents wreaths to two nimbused churchmen identified as high ranking bishops by their pallia, an item of clothing which bishop Eufrasius notably lacks. On the right is Severus and, on the left, Hermagoras $^{109}$. The semi-legendary Hermagoras is by tradition the founder of the church of Aquileia and the first bishop. In late antiquity, Augustas's province of $V \mathcal{E} H$ - region $\mathrm{X}$ - was still an ecclesiastical province whose metropolitan bishop was the bishop of Aquiliea, to whom the bishop of Parentium was suffragan. The authority over Parentium of the see of Aquileia is visually rendered by the presence of its saintly first bishop in the side apse mosaic. Agnellus of Ravenna's account of the mid fourth century Severus as saint, confessor, and eleventh bishop of Ravenna ${ }^{110}$ may be mostly legendary, but its considerable length and hagiographic nature indicate a definite prominence for Saint Severus. The veneration of Severus is attested when bishop Peter III begins a church dedicated to Severus at Classe in the $570{ }^{111}$. At Sant'Appolinare in Classe full figure mosaics of Severus and three other Ravennate bishops are in a lower register below the central apse mosaic featuring Saint Appolinaris himself, first bishop of Ravenna. They all wear the pallium. This church was begun under bishop Ursicinus (533-536), but the mosaic decoration of 546-549 is from the time of Maximian, who consecrated the church ${ }^{112}$. Maximian can also be seen wearing the pallium in his own portrait in San Vitale (Fig.7). In his entry on bishop John I (477-494) Agnellus of Ravenna writes that "John first accepted from that emperor [Valentinian III, r. 425-455] the pallium of pure

\footnotetext{
105 Author's emphasis on the one. Price, The Acts, 2, 123.

${ }^{106}$ Procopius, Buildings, 63.

${ }^{107}$ Ibid., 175 .

${ }^{108}$ See CYRRHUS in A.P. KAZHDAN, The Oxford Dictionary of Byzantium, Oxford, 1991, 1, p. 574.

${ }^{109}$ The name of the figure on the left is gone. For the identification of Hermagoras see TERRY and MAGUIRE, Dynamic Splendor, 1: 122-123.

110 See Agnellus of Ravenna, LPR, 109-114.

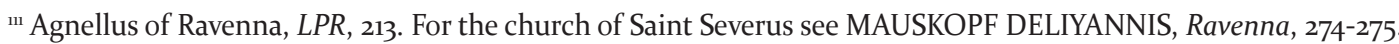

${ }^{112}$ For Sant'Apollinare in Classe see Deborah MAUSKOPF DELIYANNIS, Ravenna in Late Antiquity (Cambridge: Cambridge University Press, 2010), 259-274, and Joachim POESCHKE, Italian Mosaiacs, 300-130o (New York: Abbeville Press, 2010), p. 178-19o.
} 
wool, as is the custom of the bishop of the Romans to wear over his surcoat, which he [John] and his successors have used up to the present day"13. In his entry on bishop Maximian, Angellus of Ravenna writes that Justinian "ordered Maximian to be consecrated by Pope Vigilius" and "having given him the pallium sent him to Ravenna"114. Whether an emperor ever bestowed a pallium on a bishop of Ravenna cannot be proved from the LPR. In the first case, the dates of emperor and bishop do not coincide, indicating an error on the part of the author in using his source, which, in any event, is thought to be a forgery ${ }^{115}$. What we can infer from the $L P R$ is the importance attached to the pallium in the time of Agnellus of Ravenna, and which is already evident in the mosaics from San Vitale and Sant'Appolinare in Classe during the time of Maximian ${ }^{116}$. At San Mauro, Severus, venerated saint, confessor and bishop, wearing his pallium, has been chosen (by Maximian?) to represent the see of Ravenna. It was under Maximian that Justinian elevated the Ravennate see to archepicsopal status, making it (at least) the equal of the see of Aquileia, and this is suggested in the mosaic. Hermagoras (Aquileia) and Severus (Ravenna), each wearing the pallium, stand on equal footing and simultaneously receive their wreaths from Christ, and so the authority of Ravenna at Parentium is also visually rendered. This is the same composition as the north apse where the equally saintly brothers, Cosmas and Damian, so receive their wreaths.

The iconography of the mosaic program of the central apse at San Mauro can be read as a visual statement of imperial religious policy as codified at Constantinople II: the doctrine of Theotokos as bearer of the incarnate Word; the oneness of Christ after the hypostatic union; theopaschism, i.e. that it was this Christ, God the Word, the Son, who died on the cross for human redemption. Rather than containing any overt or covert propaganda on behalf of a "Three Chapters" schism, the mosaic program represents an implicit condemnation of Nestorius and Theodore. The two side apses complement this Justinianic motif by referencing Justinian's personal devotion to Saints Cosmas and Damian and his elevation of the see of Ravenna under his close associate, Maximian, to an archbishopric, in effect creating a rival to Rome on the Italian peninsula. But that is a topic for another time.

\footnotetext{
${ }^{13}$ Agnellus of Ravenna, LPR, 148.

${ }^{114}$ Ibid., 185.

"15 Ibid., 147, fn.23.

${ }^{16}$ For the importance of the pallium see MAUSKOPF DELIYANNIS, Ravenna, 84, 210-211, 270. See also MARKUS, "Carthage," 292-299.
} 